\title{
Pd(I) phosphine carbonyl and hydride complexes implicated in the palladium-catalyzed oxo process
}

Miguel Baya,${ }^{\mathrm{a} \dagger}$ Jennifer Houghton, ${ }^{\mathrm{a}}$ Denes Konya, ${ }^{\mathrm{b}}$ Yohan Champouret, ${ }^{\mathrm{a}}$ Jean-Claude Daran, ${ }^{\mathrm{a}}$

Karina Q. Almeida Leñero, ${ }^{\mathrm{b}}$ Lodewijk Schoon, ${ }^{\mathrm{b}}$ Wilhelmus P. Mul, ${ }^{* \mathrm{~b}}$ A. Bart van Oort, ${ }^{\mathrm{b}}$

Nicolaas Meijboom, ${ }^{\mathrm{b}}$ Eite Drent ${ }^{\mathrm{b}}$ A. Guy Orpen ${ }^{\mathrm{c}}$ and Rinaldo Poli*a

${ }^{a}$ Laboratoire de Chimie de Coordination, UPR CNRS 8241 liée par convention à l'Université Paul Sabatier et à l'Institut National Polytechnique de Toulouse, 205 Route de Narbonne,

31077 Toulouse Cedex, France

' Shell Global Solutions International B.V. Amsterdam, PO Box 38000, 1030 BN Amsterdam,

The Netherlands.

'School of Chemistry, University of Bristol, Cantock's Close, Bristol, UK BS8 1TS.

Corresponding author: Rinaldo Poli, fax: +33-561553003, poli@lcc-toulouse.fr

†Present address: Departamento de Química Inorgánica, Instituto de Ciencia de Materiales de Aragón, Universidad de Zaragoza-CSIC, 50009 Zaragoza, Spain.

${ }^{\S}$ Present address: Leiden Institute of Chemistry, Gorlaeus Laboratories, Leiden University, P.O. Box 9502, 2300 RA Leiden, The Netherlands. 


\begin{abstract}
Reduction of compound "Pd(bcope $)(\mathrm{OTf})_{2}$ " [bcope $=\left(c-\mathrm{C}_{8} \mathrm{H}_{14}-1,5\right) \mathrm{PCH}_{2} \mathrm{CH}_{2} \mathrm{P}\left(c-\mathrm{C}_{8} \mathrm{H}_{14}-1,5\right)$; OTf $\left.=\mathrm{O}_{3} \mathrm{SCF}_{3}\right]$, with $\mathrm{H}_{2} / \mathrm{CO}$ yields a mixture of $\mathrm{Pd}(\mathrm{I})$ compounds $\left[\mathrm{Pd}_{2}(\text { bcope })_{2}(\mathrm{CO})_{2}\right](\mathrm{OTf})_{2}$ (1) and $\left.\left[\mathrm{Pd}_{2} \text { (bcope) }\right)_{2}(\mu-\mathrm{CO})(\mu-\mathrm{H})\right](\mathrm{OTf})(2)$, whereas reduction with $\mathrm{H}_{2}$ or $\mathrm{Ph}_{3} \mathrm{SiH}$ in the absence of $\mathrm{CO}$ leads to $\left[\mathrm{Pd}_{3}(\text { bcope })_{3}\left(\mu_{3}-\mathrm{H}\right)_{2}\right](\mathrm{OTf})_{2}(\mathbf{3})$. Exposure of $\mathbf{3}$ to $\mathrm{CO}$ leads to $\mathbf{1}$ and $\mathbf{2}$. The structures of $\mathbf{1}$ and $\mathbf{3}$ have been determined by X-ray diffraction. Complex $\left[\mathrm{Pd}_{2}(\mathrm{bcope})_{2}-\right.$ $\left.(\mathrm{CO})_{2}\right]^{2+}$ displays a metal-metal bonded structure with a square planar environment for the $\mathrm{Pd}$ atoms and terminally bonded CO ligands and is fluxional in solution. DFT calculations aid the interpretation of this fluxional behaviour as resulting from an intramolecular exchange of the two inequivalent $\mathrm{P}$ atom positions via a symmetric bis-CO-bridged intermediate. A cyclic voltammetric investigation reveals a very complex redox behaviour for the "Pd(bcope)(OTf) 2 "/CO system and suggests possible pathways leading to the formation of the various observed products, as well as their relationship with the active species of the $\mathrm{PdL}_{2}{ }^{2+} / \mathrm{CO} / \mathrm{H}_{2}$-catalyzed oxo processes $\left(\mathrm{L}_{2}=\right.$ diphosphine ligands $)$.
\end{abstract}




\section{Introduction}

Palladium catalysis is a cornerstone in organic synthesis and fine chemicals industry. ${ }^{1-3}$ The particular class of $\mathrm{L}_{2} \mathrm{PdX}$ derivatives, where $\mathrm{L}_{2}$ stands for a bidentate ligand (phosphine, pyridine or thioether) and $\mathrm{X}$ represents a weakly or non-coordinating anion (most typically $\mathrm{CF}_{3} \mathrm{SO}_{3}=\mathrm{OTf}$, OTs or $\mathrm{CF}_{3} \mathrm{CO}_{2}$ ), has long been of interest to both academic and industrial researchers as an efficient catalytic system for CO-olefin copolymerization. ${ }^{4-7}$ This catalytic system, however, has also been shown to perform other transformations such as the hydrocarbonylation of olefins to generate monomeric aldehydes, alcohols, ketones, or esters. ${ }^{8}$ The product selectivity critically depends on the basicity of the $\mathrm{L}_{2}$ ligand and on the acidity of the $\mathrm{HX}$ reagent (the catalyst is usually prepared in situ from $\mathrm{Pd}(\mathrm{OAc})_{2}, \mathrm{~L}_{2}$ and $\mathrm{HX}$ ), as well as on the amount of $\mathrm{H}_{2}$ used in the process. The general mechanism shown in Scheme 1, where all metal species are positively charged, has been proposed for the reaction carried out in aprotic solvents such as diglyme, leading to saturated and unsaturated ketones by hydroacylation, to aldehydes and alcohols by hydroformylation with or without subsequent hydrogenation, or to polyketones by copolymerization. ${ }^{8}$ When the reactions are conducted in methanol, esters, ketoesters and other compounds may also arise from methanolysis processes. 5 


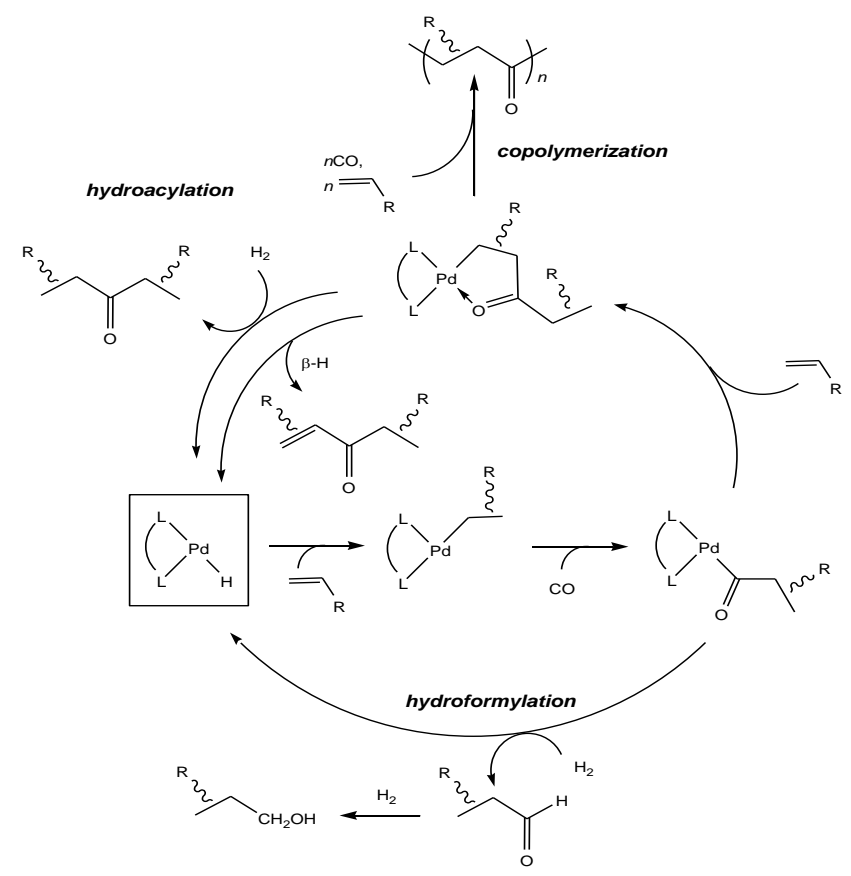

\section{Scheme 1}

More recently, it has been shown that this catalytic system, for the specific case of $\mathrm{L}_{2}=$ (c- $\left.\mathrm{C}_{8} \mathrm{H}_{14}-1,5\right) \mathrm{PCH}_{2} \mathrm{CH}_{2} \mathrm{P}\left(c-\mathrm{C}_{8} \mathrm{H}_{14}-1,5\right)$ (bcope), is also an efficient olefin isomerization catalyst. ${ }^{9}$ This has allowed the optimization of experimental conditions leading to highly selective transformations of internal olefins to linear alcohols by simultaneous isomerization hydroformylation - hydrogenation in the presence of $\mathrm{CO} / \mathrm{H}_{2}$ (syngas). In all cases, the key catalytic intermediate is proposed to be a cationic three-coordinate $\mathrm{Pd}(\mathrm{II})$ hydride complex, $\left[\mathrm{L}_{2} \mathrm{Pd}(\mathrm{H})\right]^{+}$. This appears to be an extremely reactive intermediate and has never been isolated or detected. A number of model systems have been studies in different groups using other ligands and olefins, ${ }^{10-24}$ for which intermediates could be detected or sometimes isolated. However, while such model studies provide valuable information, the translation of these results to the "real" catalytic system is not straightforward. In this contribution, we report synthetic and electrochemical investigation of the $\left[\mathrm{Pd}(\right.$ bcope $\left.)(\mathrm{OTf})_{2}\right]$ pre-catalyst under typical catalytic conditions, except for the absence of the olefin. The results that we have obtained provide, we believe, valuable new information on the nature of some of the 
compounds that are involved in the catalytic cycle or off-loop species, while revealing the extreme complexity of palladium chemistry with this particular coordination environment under reducing conditions.

\section{Results and Discussion}

\section{(a) Structural characterization of the starting material}

Our study has started with the crystallization and structural characterization of the starting compound, "Pd(bcope $)(\mathrm{OTf})_{2}$ ". This is an air stable material and is used as a catalytic precursor, thus its intimate structure is of interest. Single crystals grown from chloroform are monoclinic and display two independent $\left[\mathrm{Pd}(\text { bcope })\left(\mathrm{H}_{2} \mathrm{O}\right)_{2}\right]^{2+}$ cations, four independent $\mathrm{TfO}^{-}$anions and an additional interstitial $\mathrm{H}_{2} \mathrm{O}$ molecule in the asymmetric unit. Thus, the compound should be described as $\left[\mathrm{Pd}(\mathrm{bcope})\left(\mathrm{H}_{2} \mathrm{O}\right)_{2}\right](\mathrm{OTf})_{2} \cdot \mathrm{H}_{2} \mathrm{O}$. Given that an anhydrous solvent was used for the crystallization, we deduce that the compound is probably hygroscopic and incorporates water when kept in moist air. ${ }^{25}$ The Pd complex shows the expected square planar configuration with two cis positions occupied by the chelating bcope ligand and the remaining ones filled by aqua ligands, see Figure 1. The $\mathrm{H}_{2} \mathrm{O}$ ligands are connected to the triflate counterions and to the interstitial water molecule by H-bonding, building an intricate network. Selected bond distances and angles are collected in Table 1, whereas significant H-bonding contacts are reported as Supporting Information. The structure of a methanol solvate of the same compound, $\left[\mathrm{Pd}(\mathrm{bcope})(\mathrm{MeOH})_{2}\right](\mathrm{OTf})_{2} \cdot 2 \mathrm{MeOH}$, crystallized from a cooled methanol solution, has also been recently reported. ${ }^{25}$ 


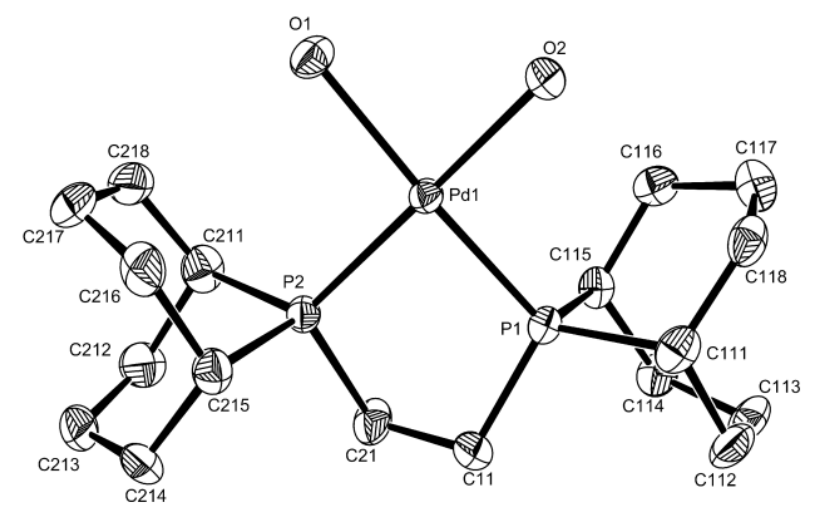

Figure 1. ORTEP view of one of the two independent dications in compound $\left[\mathrm{Pd}(\right.$ bcope $\left.)\left(\mathrm{H}_{2} \mathrm{O}\right)_{2}\right](\mathrm{OTf})_{2} \cdot \mathrm{H}_{2} \mathrm{O}$. Ellipsoids are drawn at the $50 \%$ probability level and $\mathrm{H}$ atoms are not shown for clarity.

Table 1. Selected bond distances $(\AA)$ and angles $\left(^{\circ}\right)$ for complex $\left[\mathrm{Pd}(\text { bcope })\left(\mathrm{H}_{2} \mathrm{O}\right)_{2}\right]^{2+}$.

\begin{tabular}{|l|c|l|c|}
\hline Distances & & & \\
\hline Pd1-P1 & $2.2393(11)$ & Pd2-P3 & $2.2422(11)$ \\
\hline Pd1-P2 & $2.2407(11)$ & Pd2-P4 & $2.2427(11)$ \\
\hline Pd1-O1 & $2.154(3)$ & Pd2-O3 & $2.129(3)$ \\
\hline Pd1-O2 & $2.127(3)$ & Pd2-O4 & $2.150(3)$ \\
\hline Angles & & & \\
\hline P1-Pd1-P2 & $84.20(4)$ & P3-Pd2-P4 & $84.14(4)$ \\
\hline P1-Pd1-O1 & $170.47(9)$ & P3-Pd2-O3 & $175.67(9)$ \\
\hline P1-Pd1-O2 & $97.23(9)$ & P3-Pd2-O4 & $95.52(9)$ \\
\hline P2-Pd1-O1 & $95.95(9)$ & P4-Pd2-O3 & $97.45(8)$ \\
\hline P2-Pd1-O2 & $175.56(10)$ & P4-Pd2-O4 & $170.19(9)$ \\
\hline O1-Pd1-O2 & $83.33(12)$ & O3-Pd2-O4 & $83.60(11)$ \\
\hline
\end{tabular}

\section{(b) Syntheses}

The reduction of $\left[\mathrm{Pd}(\right.$ bcope $\left.)\left(\mathrm{H}_{2} \mathrm{O}\right)_{2}\right](\mathrm{OTf})_{2}$ under a $1: 1 \quad \mathrm{CO} / \mathrm{H}_{2}$ mixture (syngas) proceeds smoothly, yielding a mixture of two products: a dinuclear $\mathrm{Pd}(\mathrm{I})$ carbonyl product, $\left[\mathrm{Pd}_{2}(\text { bcope })_{2}(\mathrm{CO})_{2}\right](\mathrm{OTf})_{2}, \mathbf{1}$, and a mixed hydrido carbonyl derivative, $[($ bcope $) \mathrm{Pd}(\mu-\mathrm{CO})(\mu-$ H)Pd(bcope)](OTf), 2, see Scheme 2. We presume that the metal is reduced by $\mathrm{H}_{2}$ to yield triflic acid, since no reaction occurs upon exposure to a neat $\mathrm{CO}$ atmosphere. This contrasts with the reported reduction of $\left[\mathrm{Pd}(\mathrm{dppm})(\mathrm{OTf})_{2}\right]$ by $\mathrm{CO}$ in the presence of water, which yields $\left[\mathrm{Pd}_{2}(\mu-\mathrm{dppm})_{2}(\mathrm{OTf})_{2}\right],\left[\mathrm{Pd}_{2}(\mu-\mathrm{dppm})_{2}(\mu-\mathrm{CO})(\mathrm{OTf})_{2}\right]$ or $\left[\mathrm{Pd}_{3}(\mu-\mathrm{dppm})_{3}\left(\mu_{3}-\mathrm{CO}\right)\left(\mu_{3}-\mathrm{OTf}\right)\right] \mathrm{OTf}$ 
depending on the amount of $\mathrm{CO}^{26}$ The greater assembling power and/or poorer donating ability of dppm relative to bcope may be responsible for this difference.

In addition, the reduction of the analogous $\left[\mathrm{Pd}(\mathrm{dppp})(\mathrm{OTf})_{2}\right]$ compound by $\mathrm{H}_{2}$ was previously reported to yield $\left[\mathrm{Pd}_{2}(\mathrm{dppp})_{2}\right](\mathrm{OTf})_{2} \cdot{ }^{27}$ The stoichiometry of the reaction leading to the dicarbonyl product is shown in Equation 1, whereas that leading to the hydrido-bridged product is in Equation 2. The hydrido-bridged cation $\mathbf{2}$ is related to the previously reported $\left[\mathrm{Pd}_{2}(\operatorname{dippp})_{2}(\mu-\mathrm{CO})(\mu-\mathrm{H})\right]^{+}$complex $\left[\operatorname{dippp}=i \operatorname{Pr}_{2} \mathrm{P}\left(\mathrm{CH}_{2}\right)_{3} \mathrm{PiPr}_{2}\right] .{ }^{28}$ The stoichiometry of the dicarbonyl product, on the other hand, is unprecedented. Although not fully mapped, the ratio 1/2 may depend on variables like solvent, pressure, reaction time and initial concentration of the precursor, as shown by IR and NMR monitoring.

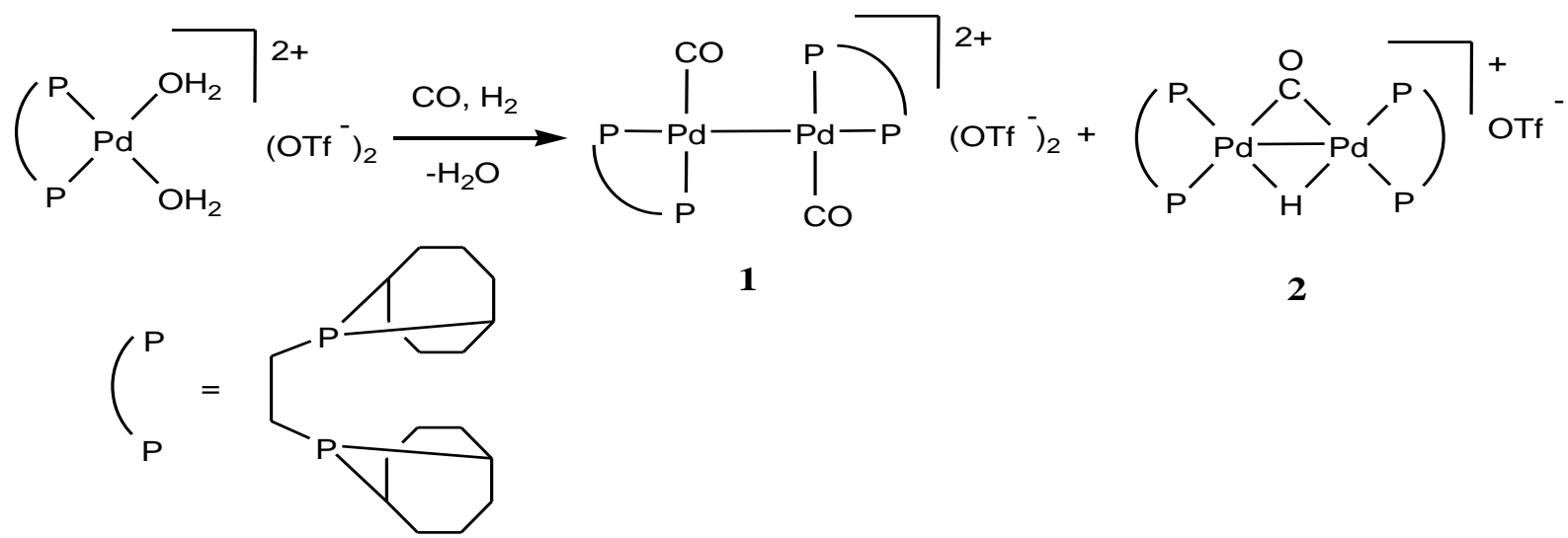

Scheme 2

$2\left[\mathrm{Pd}(\right.$ bcope $\left.)\left(\mathrm{H}_{2} \mathrm{O}\right)_{2}\right](\mathrm{OTf})_{2}+2 \mathrm{CO}+\mathrm{H}_{2} \rightarrow$

$\left[\mathrm{Pd}_{2}(\text { bcope })_{2}(\mathrm{CO})_{2}\right](\mathrm{OTf})_{2}+2 \mathrm{TfOH}+4 \mathrm{H}_{2} \mathrm{O}$

\section{Equation 1}

$2\left[\mathrm{Pd}(\right.$ bcope $\left.)\left(\mathrm{H}_{2} \mathrm{O}\right)_{2}\right](\mathrm{OTf})_{2}+\mathrm{CO}+2 \mathrm{H}_{2} \rightarrow$

$\left[\mathrm{Pd}_{2}(\text { bcope })_{2}(\mu-\mathrm{CO})(\mu-\mathrm{H})\right](\mathrm{OTf})+3 \mathrm{TfOH}+4 \mathrm{H}_{2} \mathrm{O}$ 


\section{Equation 2}

The reaction of " $\mathrm{Pd}($ bcope $)(\mathrm{OTf})_{2}$ " with syngas in $\mathrm{CD}_{3} \mathrm{OD}$ was monitored at room temperature by ${ }^{1} \mathrm{H}$ and ${ }^{31} \mathrm{P}$ NMR spectroscopy by means of a tube equipped with a Young tap fitting. At 1 bar, the colour changed immediately from yellow to orange while conversion to the dicarbonyl complex slowly took place (3\% after $8 \mathrm{~min}, 10 \%$ after $40 \mathrm{~min}$ ). After raising the pressure to 1.35 bars, the formation of the hydrido carbonyl product could also be observed ( $9 \%$ after $5 \mathrm{~min}$ ). Evidently, as suggested by the different stoichiometry, the hydrido compound should be favoured by a greater $\mathrm{H}_{2}$ pressure. At the same time, the dicarbonyl product started to precipitate while the color darkened to red-brown and the starting material was completely consumed after $35 \mathrm{~min}$. When this product mixture was further exposed to an atmosphere of pure $\mathrm{H}_{2}$, the relative amount of hydrido-carbonyl product increased and some of the precipitate redissolved, suggesting that the two products are able to interconvert under these conditions (Equation 3). Using "SWET" as a solvent, ${ }^{29} \mathbf{1}$ and $\mathbf{2}$ are formed in a ratio of about $3: 2$ under 30 bar $\mathrm{H}_{2} / \mathrm{CO}(1: 1)$ at r.t., while upon increasing the temperature to $103{ }^{\circ} \mathrm{C}$, this ratio is shifted to about $1: 4$. Upon removal of syngas, the parent compound " $\mathrm{Pd}($ bcope $)(\mathrm{OTf})_{2}$ " is reformed again, albeit slowly (taking a few days at r.t.).

$\left[\mathrm{Pd}_{2}(\text { bcope })_{2}(\mathrm{CO})_{2}\right](\mathrm{OTf})_{2}+\mathrm{H}_{2} \rightleftarrows\left[\mathrm{Pd}_{2}(\text { bcope })_{2}(\mu-\mathrm{CO})(\mu-\mathrm{H})\right](\mathrm{OTf})+\mathrm{CO}+\mathrm{TfOH}$ Equation 3

When the starting material "Pd(bcope $)(\mathrm{OTf})_{2}$ " was exposed to $\mathrm{H}_{2}$ in the absence of $\mathrm{CO}$, on the other hand, a different compound, $\left[\mathrm{Pd}_{3}(\text { bcope })_{3}(\mathrm{H})_{2}\right](\mathrm{OTf})_{2}(\mathbf{3})$, was obtained selectively and quantitatively, see Scheme 3. The stoichiometry of this reaction is presumed to be as shown in Equation 4. Silanes are also able to yield this trinuclear species, $\mathrm{Me}_{2} \mathrm{PhSiH}$ proving the most convenient one for synthetic purposes. The stoichiometry in this case is 
presumably as shown in Equation 5, the $\mathrm{H}_{2}$ by-product resulting from the neutralization of one equivalent of $\mathrm{TfOH}$ with the $4^{\text {th }}$ equivalent of silane. The stoichiometry of this product is apparently unprecedented for palladium. The reduction of other Pd phosphine precursors has been reported to lead to different stoichiometries. As mentioned above, the reduction of $\left[\mathrm{Pd}(\mathrm{dppp})(\mathrm{OTf})_{2}\right]$ yields $\left[\mathrm{Pd}_{2}(\mathrm{dppp})_{2}\right](\mathrm{OTf})_{2} \cdot{ }^{27}$ The reduction of $\mathrm{Pd}(\operatorname{dippp}) \mathrm{I}_{2}$ by $\mathrm{KBEt}_{3} \mathrm{H}$ affords $\mathrm{Pd}_{2}(\mathrm{dippp})_{2}(\mu-\mathrm{H})_{2},{ }^{30}$ whereas the reduction of $\mathrm{Pd}_{2} \mathrm{Cl}_{2}(\mathrm{dppm})_{2}$ by $\mathrm{NaBH}_{4}{ }^{31}$ leads to a product formulated as $\left[\mathrm{Pd}_{4}(\mathrm{dppm})_{4}(\mu-\mathrm{H})_{2}\right]^{2+} \cdot 32,33$ It seems that the nature of the reduced hydride product is highly phosphine dependent. Only one other hydride derivative of a triangular $\mathrm{Pd}_{3}$ cluster, $\left[\mathrm{Pd}_{3}(\mathrm{dppm})_{3}\left(\mu_{3}-\mathrm{CO}\right)\left(\mu_{3}-\mathrm{H}\right)\right]^{+}$, has been described quite recently. ${ }^{34} \mathrm{~A}$ dication having the same stoichiometry as the presently described $\left[\mathrm{Pd}_{3}(\text { bcope })_{3}(\mathrm{H})_{2}\right]^{2+}$ cluster is known for platinum, $\left[\mathrm{Pt}_{3}(\mathrm{dppm})_{3}(\mathrm{H})_{2}\right]^{2+}$, although it was not structurally characterized. ${ }^{35,36}$

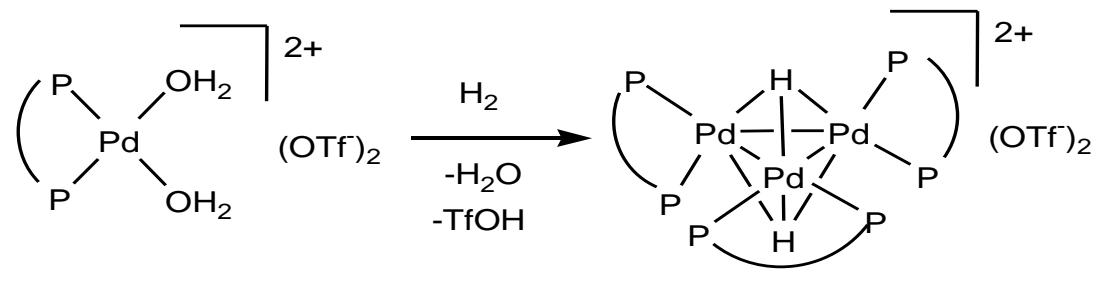

3

Scheme 3

$3\left[\mathrm{Pd}(\right.$ bcope $\left.)\left(\mathrm{H}_{2} \mathrm{O}\right)_{2}\right](\mathrm{OTf})_{2}+3 \mathrm{H}_{2} \rightarrow$

$\left[\mathrm{Pd}_{3}(\text { bcope })_{3}\left(\mu_{3}-\mathrm{H}\right)_{2}\right](\mathrm{OTf})_{2}+4 \mathrm{TfOH}+6 \mathrm{H}_{2} \mathrm{O}$

Equation 4

$3\left[\mathrm{Pd}(\right.$ bcope $\left.)\left(\mathrm{H}_{2} \mathrm{O}\right)_{2}\right](\mathrm{OTf})_{2}+4 \mathrm{PhMe}_{2} \mathrm{SiH} \rightarrow$

$\left[\mathrm{Pd}_{3}(\text { bcope })_{3}\left(\mu_{3}-\mathrm{H}\right)_{2}\right](\mathrm{OTf})_{2}+4 \mathrm{TfOSiMe}_{2} \mathrm{Ph}+\mathrm{H}_{2}+6 \mathrm{H}_{2} \mathrm{O}$

\section{Equation 5}


Interestingly, the trinuclear product also forms on gradually warming "Pd(bcope)(OTf)2" in the presence of methanol or ethanol, albeit slowly (few \% after several hours at $75^{\circ} \mathrm{C}$ ). The alcohol is presumably acting as reducing agent in this case, according to the hypothetical mechanism shown in Scheme 4 (for EtOH). According to this mechanism, conversion of " $\mathrm{Pd}(\mathrm{bcope})(\mathrm{OTf})_{2}$ " to compound $\mathbf{3}$ is expected to occur with any higher primary and secondary aliphatic alcohol. When exposed to a $\mathrm{CO}$ atmosphere (2 bar), complex 3 reacts to form a mixture of $\mathbf{1}$ (minor) and $\mathbf{2}$ (major). This procedure allowed the recovery, after crystallization of the less soluble $\mathbf{1}$, of the hydrido carbonyl product in a relatively pure form (according to the NMR).

$3\left[\mathrm{Pd}(\right.$ bcope $\left.)\left(\mathrm{OH}_{2}\right)_{2}\right](\mathrm{OTf})_{2}+3 \mathrm{EtOH} \rightarrow$

$3\left[\mathrm{Pd}(\right.$ bcope $\left.)(\mathrm{EtOH})\left(\mathrm{H}_{2} \mathrm{O}\right)\right](\mathrm{OTf})_{2}+3 \mathrm{H}_{2} \mathrm{O}$

$3\left[\mathrm{Pd}(\right.$ bcope $\left.)(\mathrm{EtOH})\left(\mathrm{H}_{2} \mathrm{O}\right)\right](\mathrm{OTf})_{2} \rightarrow 3\left[\mathrm{Pd}(\mathrm{bcope})(\mathrm{OEt})\left(\mathrm{H}_{2} \mathrm{O}\right)\right](\mathrm{OTf})+3 \mathrm{TfOH}$

$3\left[\mathrm{Pd}(\right.$ bcope $\left.)(\mathrm{OEt})\left(\mathrm{H}_{2} \mathrm{O}\right)\right](\mathrm{OTf}) \rightarrow 3\left[\mathrm{Pd}(\right.$ bcope $\left.) \mathrm{H}\left(\mathrm{H}_{2} \mathrm{O}\right)\right](\mathrm{OTf})+3 \mathrm{CH}_{3} \mathrm{CHO}$

$3\left[\mathrm{Pd}(\right.$ bcope $\left.) \mathrm{H}\left(\mathrm{H}_{2} \mathrm{O}\right)\right](\mathrm{OTf}) \rightarrow\left[\mathrm{Pd}_{3}(\text { bcope })_{3}(\mu-\mathrm{H})_{2}\right](\mathrm{OTf})_{2}+\mathrm{TfOH}+3 \mathrm{H}_{2} \mathrm{O}$

Scheme 4

(c) Spectroscopic characterization

The IR spectrum of compound $\mathbf{1}$ in the CO stretching region shows two bands at 2084 and $2066 \mathrm{~cm}^{-1}$ in $\mathrm{CH}_{2} \mathrm{Cl}_{2}$, indicating that the $\mathrm{CO}$ ligands are terminally bonded to the $\mathrm{Pd}$ centres. No bands are observed in the region typical of bridging CO ligands above the noise level. The $\mathrm{Pd}(\mathrm{I})$ product is stable under $\mathrm{CO}$, but its solutions change color from yellow to orange and then red if kept without a protecting $\mathrm{CO}$ atmosphere. Contemporarily, new broad resonances at $\delta 28$ and 32 (in $\mathrm{CD}_{2} \mathrm{Cl}_{2}$ ) develop in the ${ }^{31} \mathrm{P}$ NMR spectrum and the $\mathrm{CO}$ stretching bands completely disappear, without being replaced by any new band. The solution color changes back to yellow and these new resonances disappear when $\mathrm{CO}$ is bubbled 
through the solution, indicating the occurrence of a reversible $\mathrm{CO}$ dissociation. The freshly prepared solid is yellow if isolated as a powder, and darkened to orange as a function of storage time when kept under Ar. However, well-formed crystals are red. The product(s) of this CO dissociation is(are) CO-free, possibly related to the above-mentioned $\left[\mathrm{Pd}_{2}(\mathrm{dppp})_{2}\right](\mathrm{OTf})_{2}{ }^{27}$ No attempts were made to isolate or further investigate this(ese) product(s).

The ${ }^{31} \mathrm{P}$ NMR spectrum of $\left[\mathrm{Pd}_{2}(\text { bcope })_{2}(\mathrm{CO})_{2}\right]^{2+}$ shows a single resonance at $\delta 50.0$ in $\mathrm{CD}_{2} \mathrm{Cl}_{2}$ at room temperature, which decoalesces upon cooling, yielding two resonances in a 1:1 ratio at low temperatures (Figure 2). This is indicative of signal averaging because of the rapid exchange of two inequivalent positions. No P-P coupling could be discerned at the lowest temperature reached in this study. A slight upfield shift is also observed upon cooling. The possible intervention of a temperature dependent equilibrium between two isomers (i.e. with terminal and bridging $\mathrm{CO}$, vide infra) seems excluded by the absence of characteristic IR absorptions for bridging CO ligands, as mentioned above. The lineshape analysis (excluding the lowest temperature spectrum, which is artificially broadened by the increased solvent viscosity near the freezing point) yields the activation parameters for the exchange process: $\Delta \mathrm{H}^{\ddagger}=9.9 \pm 0.7 \mathrm{kcal} \mathrm{mol}^{-1}$ and $\Delta \mathrm{S}^{\ddagger}=-5 \pm 3 \mathrm{cal} \mathrm{mol}^{-1} \mathrm{~K}^{-1}$. The asymmetric coordination mode for the bcope ligand is confirmed by the X-ray analysis, vide infra. 


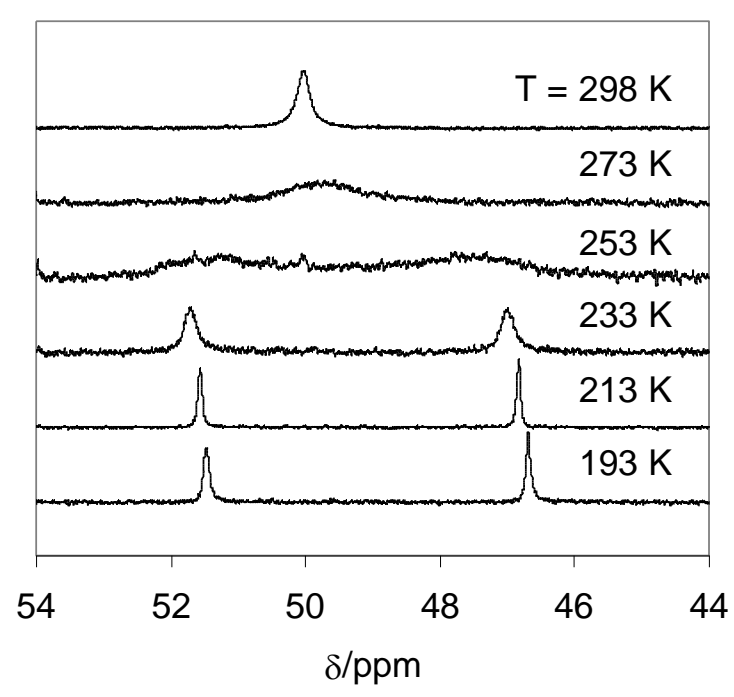

Figure 2. Variable temperature ${ }^{31} \mathrm{P}\left\{{ }^{1} \mathrm{H}\right\} \mathrm{NMR}$ spectrum of $\left[\mathrm{Pd}_{2}(\text { bcope })_{2}(\mathrm{CO})_{2}\right](\mathrm{OTf})_{2}$ in $\mathrm{CD}_{2} \mathrm{Cl}_{2}$.

The spectroscopic properties of compound $\mathbf{2}$ compare quite closely with those of the previously reported $\left[\mathrm{Pd}_{2}(\operatorname{dippp})_{2}(\mu-\mathrm{CO})(\mu-\mathrm{H})\right]^{+}$analogue. ${ }^{28}$ Particularly diagnostic is the ${ }^{1} \mathrm{H}$ resonance of the bridging hydride ligand at -5.50 in $\mathrm{CD}_{2} \mathrm{Cl}_{2}$ (quintet for $1 \mathrm{H}$ with $\mathrm{J}_{\mathrm{HP}}=46.9$ $\mathrm{Hz}$ ), whereas that of the literature analogue is at -5.17 (in $\mathrm{CD}_{3} \mathrm{OD}, \mathrm{J}_{\mathrm{HP}}=41.1 \mathrm{~Hz}$ ) and the stretching vibration of the bridging carbonyl ligand at $1818 \mathrm{~cm}^{-1}$, vs. $1789 \mathrm{~cm}^{-1}$ for the literature analogue.

Compound 3 is characterized by a single hydride resonance at $\delta-6.53$ in $\mathrm{CD}_{2} \mathrm{Cl}_{2}$, integrating to two $\mathrm{H}$ atoms and split into a septet by 6 equivalent $\mathrm{P}$ nuclei $\left(\mathrm{J}_{\mathrm{PH}}=36.9 \mathrm{~Hz}\right)$. This indicates that the hydride ligands are equivalent and occupy highly symmetric positions, as suggested in Scheme 3. The $\mathrm{P}$ nuclei afford a single ${ }^{31} \mathrm{P}$ NMR resonance at $\delta$ 52.7. Although the spectroscopic properties do not exclude the existence of a dynamic exchange process for a less symmetric structure, the more symmetric geometry is supported by the crystallographic investigation (next section). 


\section{(d) Crystallographic analyses}

Single crystals of compound 1 were grown from a $\mathrm{MeOH} / \mathrm{Et}_{2} \mathrm{O}$ mixture. The geometry of the dinuclear dication, shown in Figure 3, reveals an unbridged metal-metal bond with a Pd-Pd distance of 2.6085(4) $\AA$. The coordination geometry around each Pd center is close to ideal square planar, the chelating bcope ligand being arranged asymmetrically with one $\mathrm{P}$ donor atom trans to the CO ligand and the other one trans to the second Pd atom. The two square planes are twisted around the Pd-Pd bond by a dihedral angle close to $90^{\circ}$, probably resulting from the ligand-ligand steric repulsion and the absence of $\mathrm{Pd}-\mathrm{Pd} \pi$ bonding. Selected bond distances and angles are collected in Table 2. It is of interest to note that the Pd-P bonds trans to the Pd-Pd bond (P1, P4) are longer than those trans to CO ligands (P2, P3), indicating that the Pd-Pd bond exerts a stronger trans influence than the CO ligand. This trend is reproduced by the DFT geometry optimization (vide infra). The Pd-P bond lengths in this complex are longer than those in the $\left[\mathrm{Pd}(\text { bcope })\left(\mathrm{H}_{2} \mathrm{O}\right)_{2}\right]^{2+}$ complex, as expected from the lower formal oxidation state and the stronger trans influence exerted by the $\mathrm{CO}$ ligand and by the Pd-Pd bond.

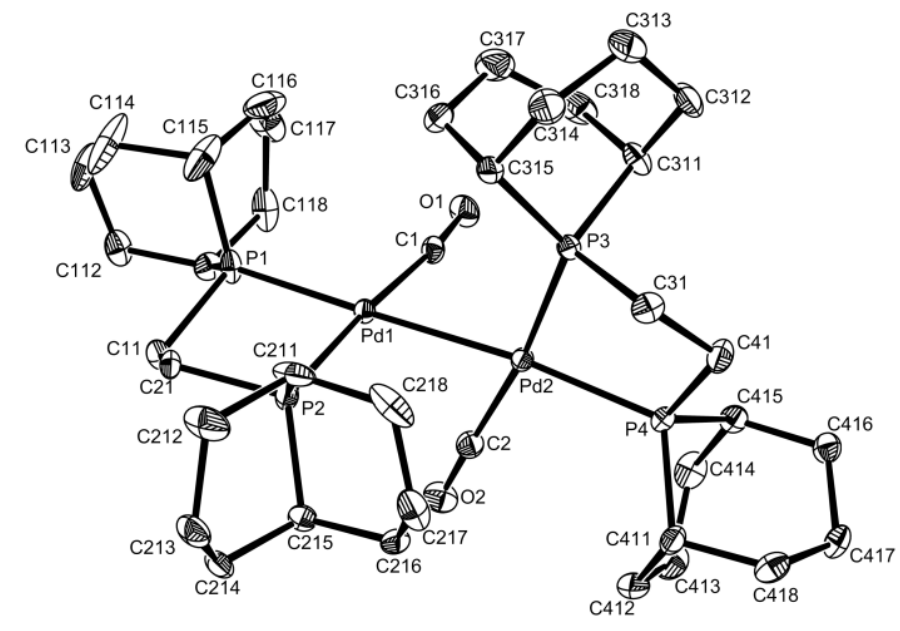

Figure 3. ORTEP view of the dication in compound $\left[\mathrm{Pd}_{2}(\text { bcope })_{2}(\mathrm{CO})_{2}\right](\mathrm{OTf})_{2}$. Ellipsoids are drawn at the $30 \%$ probability level and $\mathrm{H}$ atoms are not shown for clarity. 
Table 2. Selected bond distances $(\AA)$ and angles $\left(^{\circ}\right)$ for complex $\left[\mathrm{Pd}_{2}(\mathrm{LL})_{2}(\mathrm{CO})_{2}\right]^{2+}$ (experimental X-ray determination: $\mathrm{LL}=$ bcope; DFT calculation: $\mathrm{LL}=\mathrm{DHPE}$ ).

\begin{tabular}{|c|c|c|c|c|}
\hline & \multicolumn{2}{|c|}{ Terminal CO } & \multirow{2}{*}{$\begin{array}{c}\text { TS } \\
\text { DFT }\end{array}$} & \multirow{2}{*}{$\frac{\text { Bridging } \mathrm{CO}}{\mathrm{DFT}}$} \\
\hline & X-ray & DFT & & \\
\hline \multicolumn{5}{|l|}{ Distances } \\
\hline $\mathrm{Pd} 1-\mathrm{Pd} 2$ & $2.6085(4)$ & 2.666 & 2.830 & 2.836 \\
\hline $\mathrm{Pd1-P1}$ & $2.3407(11)$ & \multirow{2}{*}{2.436} & \multirow{2}{*}{2.409} & \multirow{2}{*}{2.422} \\
\hline $\mathrm{Pd} 2-\mathrm{P} 4$ & $2.3412(11)$ & & & \\
\hline $\mathrm{Pd} 1-\mathrm{P} 2$ & $2.3300(11)$ & \multirow{2}{*}{2.361} & \multirow{2}{*}{2.410} & \multirow{2}{*}{2.422} \\
\hline Pd2-P3 & $2.3179(11)$ & & & \\
\hline $\mathrm{Pd} 1-\mathrm{C} 1$ & $1.926(5)$ & \multirow{2}{*}{1.971} & \multirow{2}{*}{1.979} & \multirow{2}{*}{2.110} \\
\hline $\mathrm{Pd} 2-\mathrm{C} 2$ & $1.937(5)$ & & & \\
\hline $\mathrm{Pd} 1-\mathrm{C} 2$ & $2.720(5)$ & \multirow{2}{*}{3.113} & \multirow{2}{*}{2.417} & \multirow{2}{*}{2.110} \\
\hline $\mathrm{Pd} 2-\mathrm{C} 1$ & $2.896(4)$ & & & \\
\hline C1-O1 & $1.115(6)$ & \multirow{2}{*}{1.136} & \multirow{2}{*}{1.149} & \multirow{2}{*}{1.156} \\
\hline $\mathrm{C} 2-\mathrm{O} 2$ & $1.123(6)$ & & & \\
\hline \multicolumn{5}{|l|}{ Angles } \\
\hline $\mathrm{Pd} 2-\mathrm{Pd} 1-\mathrm{P} 1$ & 176.71(3) & \multirow{2}{*}{175.9} & \multirow{2}{*}{154.0} & \multirow{2}{*}{138.4} \\
\hline $\mathrm{Pd} 1-\mathrm{Pd} 2-\mathrm{P} 4$ & 174.07(3) & & & \\
\hline $\mathrm{Pd} 2-\mathrm{Pd} 1-\mathrm{P} 2$ & $97.20(3)$ & \multirow{2}{*}{92.3} & \multirow{2}{*}{120.8} & \multirow{2}{*}{138.4} \\
\hline $\mathrm{Pd} 1-\mathrm{Pd} 2-\mathrm{P} 3$ & $101.33(3)$ & & & \\
\hline $\mathrm{Pd} 2-\mathrm{Pd} 1-\mathrm{C} 1$ & $77.78(13)$ & \multirow{2}{*}{83.0} & \multirow{2}{*}{57.1} & \multirow{2}{*}{47.8} \\
\hline Pd1-Pd2-C2 & $71.78(14)$ & & & \\
\hline P1-Pd1-P2 & $85.94(4)$ & \multirow{2}{*}{83.9} & \multirow{2}{*}{83.6} & $02 ?$ \\
\hline P3-Pd2-P4 & $83.81(4)$ & & & 83.3 \\
\hline P1-Pd1-C1 & $99.09(13)$ & & & \\
\hline $\mathrm{P} 4-\mathrm{Pd} 2-\mathrm{C} 2$ & $102.85(14)$ & 100.8 & 97.7 & 90.6 \\
\hline P2-Pd1-C1 & $174.97(13)$ & 1750 & 1746 & 1728 \\
\hline $\mathrm{P} 3-\mathrm{Pd} 2-\mathrm{C} 2$ & $171.80(14)$ & $1 / 5.0$ & $1 / 4.0$ & $1 / 3.8$ \\
\hline Pd1-C1-O1 & $173.3(4)$ & 1775 & 1558 & 1377 \\
\hline $\mathrm{Pd} 2-\mathrm{C} 2-\mathrm{O} 2$ & $172.8(4)$ & $1 / 7.5$ & 155.0 & $15 \%$ \\
\hline Pd-C-Pd & - & - & 79.5 & 84.5 \\
\hline Dihedral angle & & & & \\
\hline C-Pd-Pd-C & $98.3(2)$ & 94.7 & 140.9 & 180.0 \\
\hline
\end{tabular}

According to the Cambridge Structural Database, this is the first structural determination for a $\operatorname{Pd}(\mathrm{I})$ complex containing only phosphine and carbonyl ligands. The structure is closely related to those of other unbridged dicationic $\mathrm{Pd}^{\mathrm{I}}$ complexes such as $\left[\mathrm{Pd}_{2}\left(\mathrm{PMe}_{3}\right)_{6}\right]^{2+}$ and $\left[\mathrm{Pd}_{2}(\mathrm{LL})_{2}\left(\mathrm{~L}^{\prime}\right)_{2}\right]^{2+} \mathrm{LL}=$ diphosphine; $\mathrm{L}^{\prime}=$ isocyanide $) .{ }^{37-40}$ The dihedral angle between the two square planes in these compounds is also close to $90^{\circ}$. Other related compounds are $\left[\mathrm{Pd}_{2}\left(\mathrm{PPh}_{2} \mathrm{CH}=\mathrm{CH}_{2}\right)_{2}\left(\mu-\mathrm{PPh}_{2} \mathrm{CH}=\mathrm{CH}_{2}\right)_{2}\right]^{2+},{ }^{41}\left[\mathrm{Pd}_{2}\left\{\mu-2,6-\mathrm{NC}_{5} \mathrm{H}_{3}\left(\mathrm{PPh}_{2}\right)_{2}\right\}_{2}\right]^{2+}, 42$ 
$\left[\mathrm{Pd}_{2}\left(\mu-\mathrm{Ph}_{2} \mathrm{PNHPPh}_{2}\right)_{2}\left(\mathrm{PPh}_{3}\right)_{2}\right]^{2+},{ }^{43}$ and $\left[\mathrm{Pd}_{2}\left(\mu-\mathrm{PR}_{2} \mathrm{CH}_{2} \mathrm{CH}_{2} \mathrm{P}(\mathrm{Ph}) \mathrm{CH}_{2} \mathrm{CH}_{2} \mathrm{PR}_{2}\right)_{2}\right]^{2+}(\mathrm{R}=\mathrm{Et}$, $\mathrm{Ph}),{ }^{44}$ where the presence of bridging ligands forces coplanarity. In the structure of the above-mentioned $\left[\mathrm{Pd}_{2}(\mathrm{dppp})_{2}\right](\mathrm{OTf})_{2},{ }^{27}$ coplanarity appears to be imposed by a $\mathrm{Pd}-(\pi$-arene $)$ interaction. ${ }^{45}$ The closest dinuclear carbonylpalladium(I) systems appear to be the cationic complexes $\left[\mathrm{Pd}_{2}(\mathrm{LL})_{2}(\mu-\mathrm{CO})(\mathrm{X})\right]^{+}\left(\mathrm{X}=\mathrm{H}, \mathrm{L}=\operatorname{dippp}^{28} ; \mathrm{X}=\mathrm{CH}_{3}, \mathrm{~L}=\operatorname{dippe}^{46}\right)$, where $\mathrm{CO}$ adopts, however, a bridging coordination mode. The isoelectronic neutral dihydride complex $\left[\mathrm{Pd}_{2}(\operatorname{dippp})_{2}(\mu-\mathrm{H})_{2}\right]$ also adopts a bridged structure. ${ }^{30}$ Complex $\left[\mathrm{Pd}_{2}(\mathrm{dppp})_{2}\right]^{2+}$ was shown to react with $\mathrm{CO}$ to yield $\left[\mathrm{Pd}_{2}(\mathrm{dppp})_{2}(\mathrm{CO})_{2}\right]^{2+}$, but this was only characterized in solution and described as having a probable bis(CO)-bridged structure, although the possibility for a fluctional unbridged structure, similar to that revealed spectroscopically for $\left[\mathrm{Pd}_{2}(\mathrm{dppp})_{2}(\mathrm{MeCN})_{2}\right]^{2+}$, was also advanced. ${ }^{27}$ The only other crystallographically characterized compounds containing only phosphine and CO ligands are the dinuclear $\mathrm{Pd}_{2}{ }^{0}$ complex $\left[\mathrm{Pd}_{2}\left(t \mathrm{Bu}_{2} \mathrm{PCH}_{2} \mathrm{CH}_{2} \mathrm{P} t \mathrm{Bu}_{2}\right)_{2}(\mu-\mathrm{CO})\right],{ }^{47}$ a variety of higher nuclearity clusters, ${ }^{48-51}$ and the mixed-valence $\mathrm{Pd}_{3}{ }^{0, \mathrm{I}, \mathrm{I}}$ cluster $\left[\mathrm{Pd}_{3}(\mathrm{dmpe})_{3}\left(\mu_{3}-\mathrm{CO}\right)\right]^{2+} .52-55$

The comparison of the above structures brings us to consider the aptitude of the $\mathrm{CO}$ ligand to bind a Pd center in a terminal fashion vs. bridging two or three Pd centres (e.g. I vs. II vs. III). The bridging aptitude of carbon monoxide is stronger than that of the isoelectronic isocyanide ligand, and it is favoured by a greater electron density on the metal centre. This property is nicely illustrated by the unfailing presence of bridging $\mathrm{CO}$ (type II or III) in $\mathrm{Pd}^{0}$ carbonyl clusters. Mixed-valence $\mathrm{Pd}_{3}{ }^{0, \mathrm{I}, \mathrm{I}}$ complexes also feature a bridging coordination mode (type III). For the $\mathrm{Pd}^{\mathrm{I}}$ species, the bridging mode (type II) is again observed for the neutral $\left[\mathrm{Pd}(\mu-\mathrm{CO})\left(\mu-\mathrm{O}_{2} \mathrm{CCH}_{3}\right)\right]_{4}$ complex ${ }^{56}$ and for the monocationic $\left[\mathrm{Pd}_{2}(\mathrm{dppb})_{2}(\mu-\mathrm{CO})(\mathrm{X})\right]^{+}(\mathrm{X}=$ $\left.\mathrm{H}, \mathrm{CH}_{3}\right)$ complexes. ${ }^{28,} 46$ However, going to the dicationic $\left[\mathrm{Pd}_{2}(\text { bcope })_{2}(\mathrm{CO})_{2}\right]^{2+}$ tilts the balance in favour of the terminal coordination mode $\mathbf{I}$. 


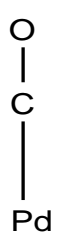

I

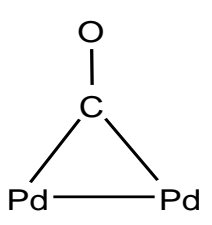

II

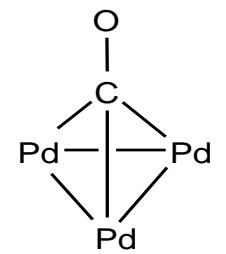

III

Well formed crystals of compound $\left[\mathrm{Pd}_{3}(\text { bcope })_{3}(\mathrm{H})_{2}\right](\mathrm{OTf})_{2}(\mathbf{3})$ as a methanol solvate were obtained and analyzed by X-ray diffraction. This crystal structure displays two independent dications in the asymmetric unit, only one of which is ordered. The second one is severely disordered (see details in the Experimental section). The structure determination, however, is sufficiently well developed to unambiguously identify the cluster geometry as shown in Scheme 3. A view of the ordered cluster is shown in Figure 4. Both independent dications sit on crystallographic threefold axes, therefore the $\mathrm{Pd}_{3}$ triangle is perfectly equilateral. The three $\mathrm{Pd}(\mathrm{bcope})$ units are arranged in propeller fashion with exact $\mathrm{C}_{3}$ and near- $\mathrm{D}_{3}$ symmetry, with the $\mathrm{P}_{2} \mathrm{Pd}$ planes being skewed relative to the $\mathrm{Pd}_{3}$ plane by $46.00(8)^{\circ}$ for the ordered cluster and $46.7(2)^{\circ}$ for the disordered one. The hydride ligands were not located but presumably triply bridge the $\mathrm{Pd}_{3}$ triangle. Note that the diphosphine ligands adopt a chelating mode in cluster $\mathbf{3}$, whereas the many crystallographically characterized $\operatorname{Pd}_{3}(\mathrm{LL})_{3}$ and $\mathrm{Pt}_{3}(\mathrm{LL})_{3}$ systems with $\mathrm{LL}=$ dppm display a bridging mode for the smaller bite diphosphinomethane ligand. ${ }^{52-55}, 57-64$ In the structure of the somewhat related $\left[\mathrm{Pt}_{3}(\mathrm{dppe})_{3}(\mathrm{H})_{3}\right]^{+}$, the diphosphine also adopts a chelating mode. ${ }^{65}$ As mentioned above, a Pt complex having the same stoichiometry, $\left[\mathrm{Pt}_{3}(\mathrm{dppe})_{3}(\mathrm{H})_{2}\right]^{2+}$, has previously been reported but not structurally characterized. ${ }^{35,36}$ A related derivative for which an X-ray structure has been determined is $\left[\mathrm{Pt}_{3}(\mathrm{dppm})_{3}(\mathrm{H})\left\{\mathrm{P}(\mathrm{OMe})_{3}\right\}\right]^{+} .66,67$ 


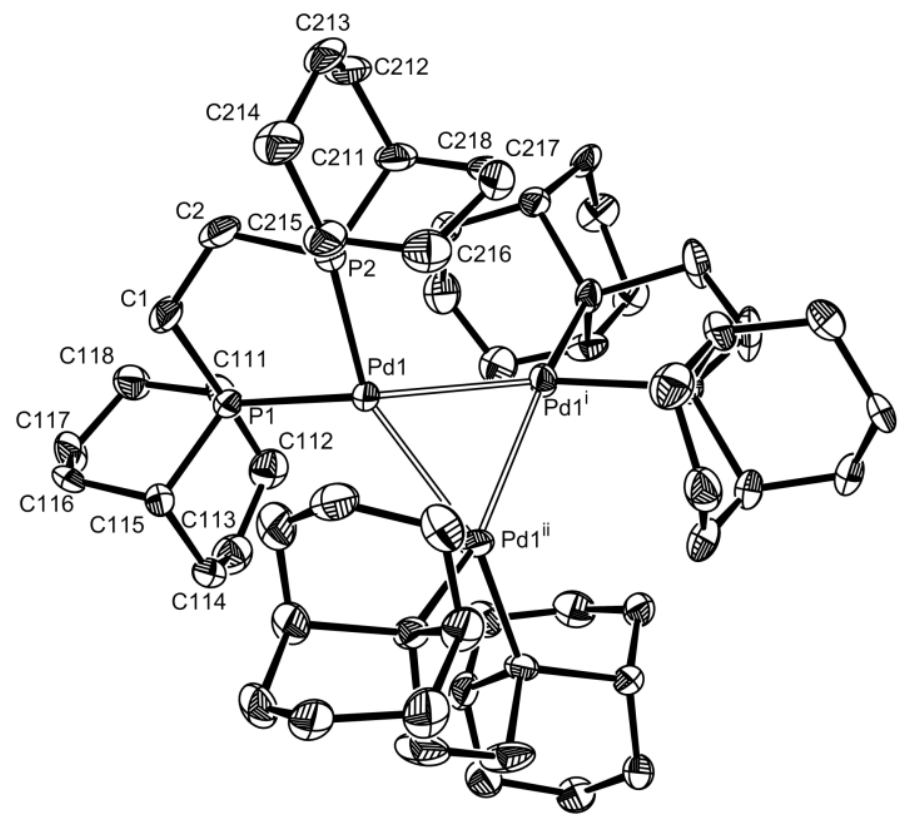

Figure 4. ORTEP view of the ordered trinuclear $\left[\mathrm{Pd}_{3}(\text { bcope })_{3} \mathrm{H}_{2}\right]^{2+}$ cluster in compound 3 . Ellipsoids are drawn at the $30 \%$ probability level and $\mathrm{H}$ atoms are not shown for clarity. Important bond distances $(\AA)$ and angles $\left({ }^{\circ}\right)$ : $\mathrm{Pd} 1-\mathrm{Pd} 1^{\mathrm{i}}, 2.8280(12)$; Pd1$\mathrm{P} 1,2.267(3)$; Pd1-P2, 2.340(3); P1-Pd1-P2, 86.85(11). The corresponding values for the disordered dication are: $\mathrm{Pd} 2-\mathrm{Pd} 2{ }^{\mathrm{i}}$, 2.800(5); $\mathrm{Pd} 2-\mathrm{P} 3,2.310(7) ; \mathrm{Pd} 2-\mathrm{P} 4$, 2.296(8); P3-Pd3-P4, 87.2(3).

\section{(e) DFT calculations}

The $\mathrm{P}$ exchange process observed in complex $\left[\mathrm{Pd}_{2}(\text { bcope })_{2}(\mathrm{CO})_{2}\right]^{2+}$ was further probed by a DFT calculation on the model system where the simpler $\mathrm{H}_{2} \mathrm{PCH}_{2} \mathrm{CH}_{2} \mathrm{PH}_{2}$ (DHPE) ligand replaces the bcope ligand. The results are summarized in Figure 5 and the DFT optimized bond distances and angles are compared with the experimental data in Table 2. The experimental geometry revealed by the crystallographic study corresponds indeed very closely to the global energy minimum. The obvious symmetric structure allowing the $\mathrm{P}$ exchange is one where the $\mathrm{CO}$ ligands rearrange from a terminal to a bridging position, similar to the structure experimentally observed for $\left[\mathrm{Pd}_{2}(\mathrm{dppb})_{2}(\mu-\mathrm{CO})(\mu-\mathrm{H})\right]^{+}$and $\left[\mathrm{Pd}_{2}(\operatorname{dippp})_{2}(\mu-\mathrm{H})_{2}\right] .{ }^{28,30}$ This structure was actually found to reside in a well defined local energy minimum, which is only $3.8 \mathrm{kcal} \mathrm{mol}^{-1}$ higher than the terminal $\mathrm{CO}$ global minimum, 
see Figure 5. The transition state leading from the terminal to the bridging $\mathrm{CO}$ structure was also optimized. It resides $6.1 \mathrm{kcal} \mathrm{mol}^{-1}$ higher than the global minimum and $2.3 \mathrm{kcal} \mathrm{mol}^{-1}$ higher than the intermediate CO-bridged structure. These results are in rather good agreement with the low P exchange barrier $\left(\Delta \mathrm{H}^{\star}=9.9 \pm 0.7 \mathrm{kcal} \mathrm{mol}^{-1}\right)$ shown by the NMR study and with the absence of a significant equilibrium population of the CO-bridged structure. Thus, it would appear that the preference for a terminal $\mathrm{CO}$ binding mode (I) relative to a bridging one (II) depends on the compound charge, as discussed above, and not on the chelating ligand nature. The square planar coordination sphere is little perturbed by the rearrangement, as signalled by the minor variation of the $\mathrm{P} 1-\mathrm{Pd}-\mathrm{P} 2$ and $\mathrm{P} 1-\mathrm{Pd}-\mathrm{CO}$ angles. The isomerization mostly involves an electronic rearrangement in the $\mathrm{Pd}_{2}(\mathrm{CO})_{2}$ moiety, as shown by the lengthening of the $\mathrm{Pd}-\mathrm{Pd}, \mathrm{Pd}-\mathrm{C}$ and $\mathrm{C}-\mathrm{O}$ distances on going from the terminal to the bridged structure.

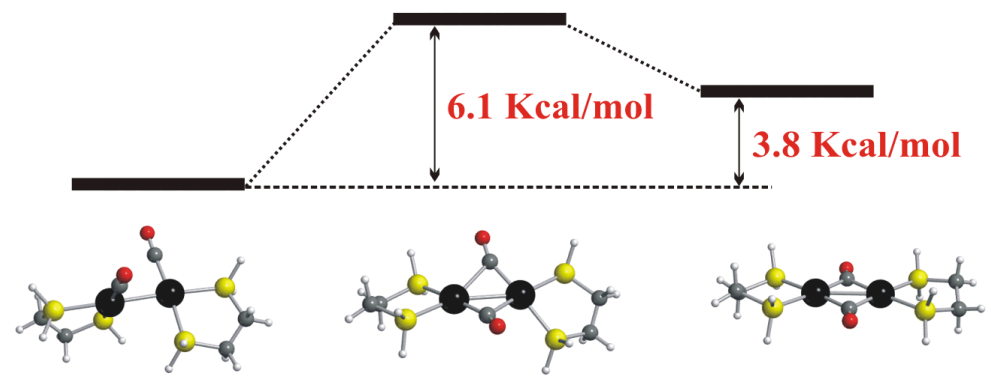

Figure 5. DFT optimized structures and relative energies of $\left[\mathrm{Pd}_{2}(\mathrm{DHPE})_{2}(\mathrm{CO})_{2}\right]^{2+}$.

\section{(f) Electrochemical studies}

In order to learn more on the reduction mechanism leading to the formation of the $\operatorname{Pd}(\mathrm{I})$ complex $\left[\mathrm{Pd}_{2}(\text { bcope })_{2}(\mathrm{CO})_{2}\right]^{2+}$, the $\mathrm{Pd}^{\mathrm{II}}$ compound $\left[\mathrm{Pd}(\text { bcope })\left(\mathrm{H}_{2} \mathrm{O}\right)_{2}\right]^{2+}$ was studied by cyclic voltammetry in $\mathrm{CH}_{2} \mathrm{Cl}_{2}$ solution, both under $\mathrm{Ar}$ and under $\mathrm{CO}$. The complete study was carried out independently on the two different working electrodes (platinum and glassy 
carbon), yielding identical results. The studies were carried out with three different supporting electrolytes: $\quad n \mathrm{Bu}_{4} \mathrm{NPF}_{6} \quad\left(\mathrm{TBAPF}_{6}\right), \quad n \mathrm{Bu}_{4} \mathrm{NO}_{3} \mathrm{SCF}_{3} \quad$ (TBAOTf), and $n \mathrm{Bu}_{4} \mathrm{~N}\left[\mathrm{~B}\left\{\mathrm{C}_{6} \mathrm{H}_{3}\left(\mathrm{CF}_{3}\right)_{2}-3,5\right\}_{4}\right]\left(\mathrm{TBABAr}_{\mathrm{F}}\right)$. This was necessary because our initial studies using the more common $\mathrm{TBAPF}_{6}$ indicated a complex behavior, attributed to ion pairing phenomena. As it has been recently shown, ${ }^{68-70}$ the use of bulkier anions in the supporting electrolyte, especially fluorinated tetraarylborates, greatly simplifies the response of electrochemical processes involving successive oxidation steps. Given the charge/size ratio, the ion paring of the above salts in $\mathrm{CH}_{2} \mathrm{Cl}_{2}$ follows the order $\mathrm{TBAPF}_{6}>\mathrm{TBAOTf}>\mathrm{TBABAr}_{\mathrm{F}}$.

The redox behavior is not well defined under Ar. Two reduction processes are visible at ca. -0.55 and $-1.0 \mathrm{~V}$ in the presence of the $\mathrm{TBAPF}_{6}$ and TBAOTf supporting electrolytes but their relative intensity is different on going from one salt to the other one. Both processes are shifted to more negative potentials in the presence of the $\operatorname{TBABAr}_{\mathrm{F}}$ salt, see Figure 6. No electrochemical activity until the solvent discharge was observed in oxidative scans, consistent with the stability of square planar $\mathrm{Pd}^{\mathrm{II}}$ toward oxidation. A more detailed analysis of these reductive processes by multiple scans and variable scan rates did not allow us to extract a clear picture of the chemical processes that are associated with the electrochemical reductions. The compound most likely decomposes to unstable products following its reduction, since there are no ligands capable to effectively stabilize the resulting lower oxidation state palladium center. Thus, a dinuclear $\left[\mathrm{Pd}_{2}(\text { bcope })_{2}\right]^{2+}$ complex similar to $\left[\operatorname{Pd}_{2}(\mathrm{dppp})_{2}\right]^{2+}$ does not appear to be stable, presumably because bcope does not have aryl substituents to occupy the vacant site as in the dppp complex. ${ }^{27}$ This difference could also explain the formation of compound 3 upon reduction with $\mathrm{H}_{2}$, whereas $\left[\mathrm{Pd}(\mathrm{dppp})(\mathrm{OTf})_{2}\right]$ yields $\left[\mathrm{Pd}_{2}(\mathrm{dppp})_{2}\right]^{2+}$. 


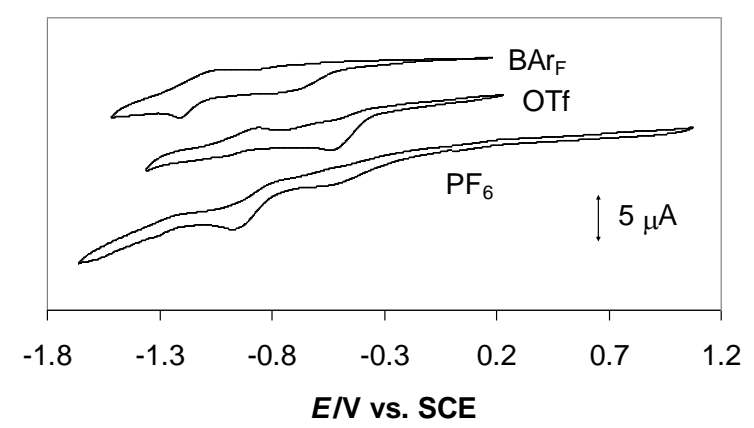

Figure 6. Cyclic voltammograms of $\mathrm{Pd}($ bcope $)(\mathrm{OTf})_{2}$ in $\mathrm{CH}_{2} \mathrm{Cl}_{2}\left(\mathrm{C}=3.5 \cdot 10^{-3} \mathrm{M}\right)$ under argon, in the presence of different $n \mathrm{Bu}_{4} \mathrm{~N}^{+}$salts as supporting electrolytes $(0.1 \mathrm{M})$. The scan rate is $100 \mathrm{mV} \mathrm{s}^{-1}$.

After placing the samples under a $\mathrm{CO}$ atmosphere, much better defined electrochemical responses were obtained. A preliminary investigation with reductive scans yields the voltammograms shown in Figure 7. Again, no electrochemical activity was observed during the oxidative scans. As can be appreciated from the Figure, the electrochemical behavior is highly dependent on the nature of the supporting electrolyte, indicating a strong influence of ion pairing effects. The first important observation concerns the potential of the first irreversible peak $\mathbf{A}$, which is ca. $-0.36 \mathrm{~V}_{\text {for }} \mathrm{PF}_{6},-0.49 \mathrm{~V}$ for OTf and $-0.52 \mathrm{~V}$ for $\mathrm{BAr}_{\mathrm{F}}$, and corresponds quite closely to the first reduction process observed under Ar. This is consistent with the absence of a chemical interaction between $\mathrm{CO}$ and the PdII complex, which is also indicated by the absence of any observable change (color and spectroscopic properties) upon exposing the $\left[\mathrm{Pd}(\text { bcope })\left(\mathrm{H}_{2} \mathrm{O}\right)_{2}\right]^{2+}$ solution to a $\mathrm{CO}$ atmosphere. Thus, peak $\mathbf{A}$ can be attributed to the reduction of mononuclear $\mathrm{Pd}^{\mathrm{II}}$ to $\mathrm{Pd}^{\mathrm{I}}$. The monoelectronic nature of this process has been confirmed coulometrically (vide infra). 


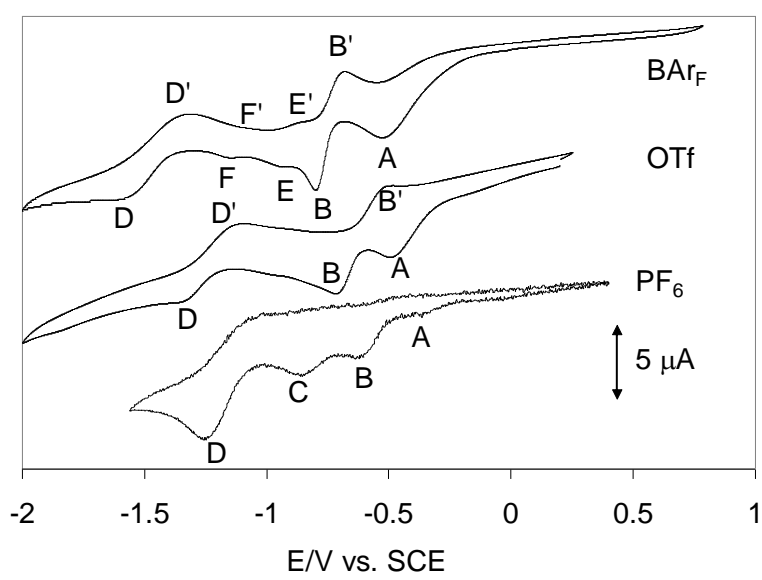

Figure 7. Cyclic voltammograms of $\mathrm{Pd}($ bcope $)(\mathrm{OTf})_{2}$ under $\mathrm{CO}$. The other conditions are identical to those in Figure 6.

The first reduction peak is followed by a second one, $\mathbf{B}$, whose position is also strongly anion-dependent $\left(-0.62 \mathrm{~V}_{\text {for }} \mathrm{PF}_{6},-0.71 \mathrm{~V}\right.$ for $\mathrm{OTf}$ and $-0.80 \mathrm{~V}$ for $\left.\mathrm{BAr}_{\mathrm{F}}\right)$. An oxidation wave $\mathbf{B}^{\prime}$ is also present, the position and relative intensity of which are quite strongly electrolytedependent (not discernible for $\mathrm{PF}_{6}$, ca $-0.5 \mathrm{~V}$ with intermediate intensity for OTf, ca. $-0.68 \mathrm{~V}$ for $\left.\mathrm{BAr}_{\mathrm{F}}\right)$. As will be shown later, this process is not associated to the reduction wave $\mathbf{B}$. At more negative potentials, two distinct reductive peaks $\mathbf{C}($ ca. $-0.86 \mathrm{~V})$ and $\mathbf{D}($ ca. $-1.25 \mathrm{~V})$, corresponding to irreversible processes, are clearly visible for the $\mathrm{PF}_{6}$ solution. For the other two solutions, peak $\mathbf{D}$ appears to be still present, though at smaller intensity and at lower potential (ca. $-1.34 \mathrm{~V}$ for OTf and ca. $-1.55 \mathrm{~V}$ for $\mathrm{BAr}_{\mathrm{F}}$ ), whereas peak $\mathbf{C}$ is not visible. An oxidation process $\mathbf{D}^{\prime}$ is more clearly visible for the OTf and $\mathrm{BAr}_{\mathrm{F}}$ solutions. On the other hand, two additional and reversible processes $\mathbf{E} / \mathbf{E}^{\prime}$ (ca. -0.90) and $\mathbf{F} / \mathbf{F}^{\prime}$ (ca. -1.10) become visible for the $\mathrm{BAr}_{\mathrm{F}}$ solution. The first one is also visible in the OTf solution under certain conditions (vide infra).

The results obtained with the $\mathrm{PF}_{6}$ supporting electrolyte are quite complex. The observed behavior very much depends on the electrode history with certain bands appearing or disappearing after polishing. Therefore, for the sake of simplicity, we shall examine and 
discuss in more detail only the results obtained with the OTf and $\mathrm{BAr}_{\mathrm{F}}$ salts, with occasional mention of the corresponding behavior in the presence of the $\mathrm{PF}_{6}$ salt. All voltammograms that will be presented and discussed have been obtained on a freshly polished working electrode (see Experimental section).

It is useful to first examine the voltammetric response for a fast $(1000 \mathrm{mV} / \mathrm{s})$, multiple scan experiment, shown in Figure 8. The behavior is nearly identical in the presence of the OTf and $\mathrm{BAr}_{\mathrm{F}}$ electrolytes. The first scan shows the prominence of peak $\mathbf{A}$, followed by peak $\mathbf{B}$ with a relatively small intensity, and by peak $\mathbf{E}$ with an intensity similar to that of $\mathbf{A}$. The $E_{C}$ value, like the $E_{A}$ value and unlike the $E_{B}$ value, is essentially identical in the presence of the two different supporting electrolytes (ca. $-1.01 \mathrm{~V}$ at this scan rate). In subsequent scans, peaks $\mathbf{A}$ and $\mathbf{E}$ drastically decrease in intensity while peak $\mathbf{B}$ remains approximately unchanged. Note also that both peaks $\mathbf{A}$ and $\mathbf{E}$ shift to less negative potentials as their intensity decreases, indicating concentration dependence for the cathodic peak potential. Peaks $\mathbf{A}$ and $\mathbf{E}$ essentially disappear after the 3rd scan for the OTf solution, whereas they remain at small intensity at dynamic equilibrium ( $>5$ th scan) for the $\mathrm{BAr}_{\mathrm{F}}$ solution. For the corresponding $\mathrm{PF}_{6}$ solution, peak $\mathbf{A}$ is visible (with a relatively small intensity) only during the first scan. At the same time, an anodic peak $(\mathbf{G})$ develops at ca. $+0.04 \mathrm{~V}$, but remains small at dynamic equilibrium and is visible only for the OTf and $\mathrm{PF}_{6}$ solutions. Peak $\mathbf{F}$ is also visible at dynamic equilibrium, but only for the $\mathrm{BAr}_{\mathrm{F}}$ solution, with a similar intensity to $\mathbf{E}$. However, contrary to $\mathbf{E}$, it is not observed during the first scan. This means that the species responsible for $\mathbf{F}$ is not a primary product of the electrochemical reduction. It is probably a species derived from either an irreversible or a reversible (equilibrium) transformation of a primary reduction product. Note also that both processes leading to $\mathbf{E}$ and $\mathbf{F}$ appear electrochemically reversible at this scan rate, since their return peaks $\mathbf{E}^{\prime}$ and $\mathbf{F}^{\prime}$ are also clearly visible. 

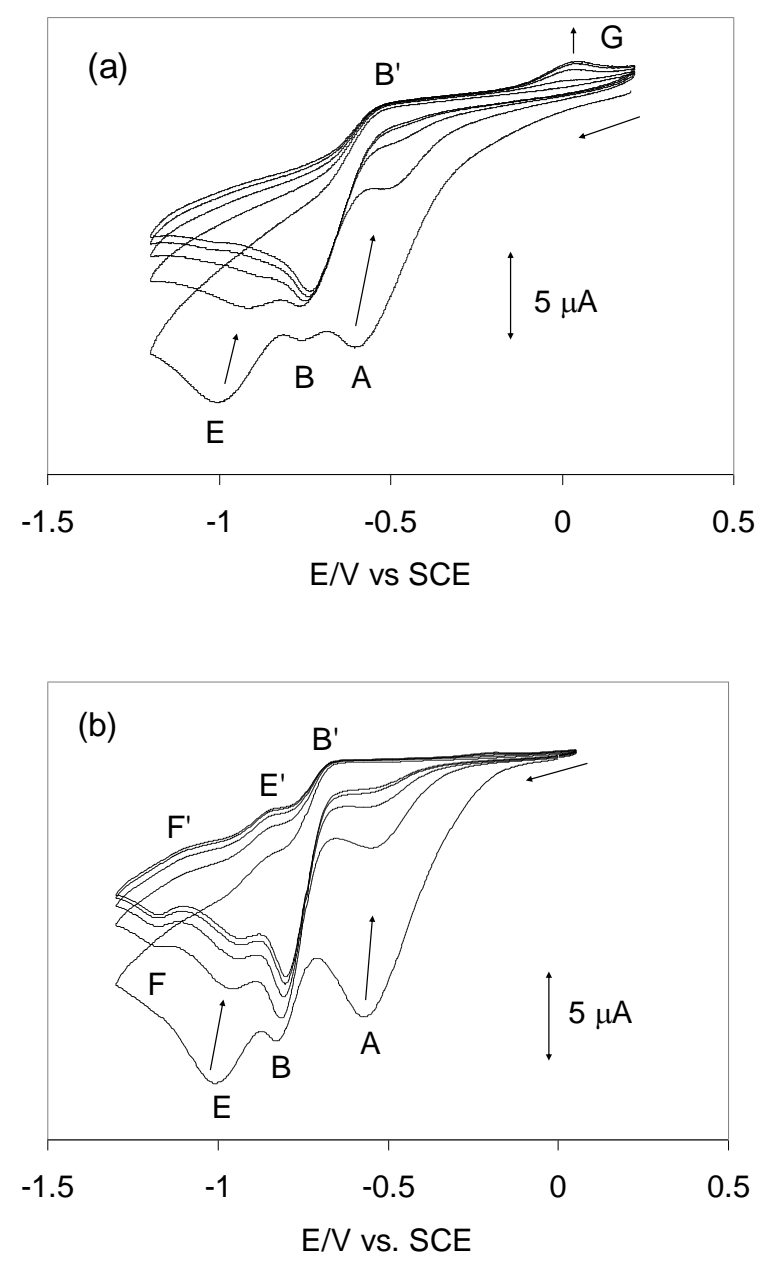

Figure 8. Five-scan cyclic voltammogram of $\mathrm{Pd}($ bcope $)(\mathrm{OTf})_{2}$ in $\mathrm{CH}_{2} \mathrm{Cl}_{2}$ under $\mathrm{CO}$ at 1000

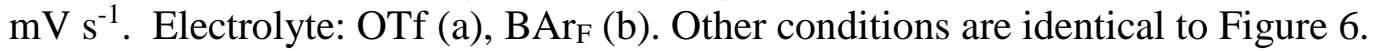

A first assignment of the main chemical processes is possible on the basis of a few parallel coulometric and cyclic voltammetric studies. Bulk reductive electrolysis under a CO atmosphere of a solution of $\mathrm{Pd}($ bcope $)(\mathrm{OTf})_{2}$ containing the TBAOTf electrolyte at a constant potential of $-0.5 \mathrm{~V}$ consumed 1.0 electrons per Pd atom, while the color of the solution did not significantly change. After electrolysis, the solution exhibited the cyclic voltammogram shown in Figure 9. Since the consumption of 1 electron per Pd atom strongly indicated the formation of complex $\left[\mathrm{Pd}_{2}(\text { bcope })_{2}(\mathrm{CO})_{2}\right] 2+$, a genuine sample of this compound was also investigated, yielding a voltammetric response identical to that shown in Figure 9. This experiment unambiguously proves that the reduction process associated to peak A involves 1- 
electron and leads to the formation of the dinuclear PdI carbonyl compound, according to the stoichiometry of Equation 6.

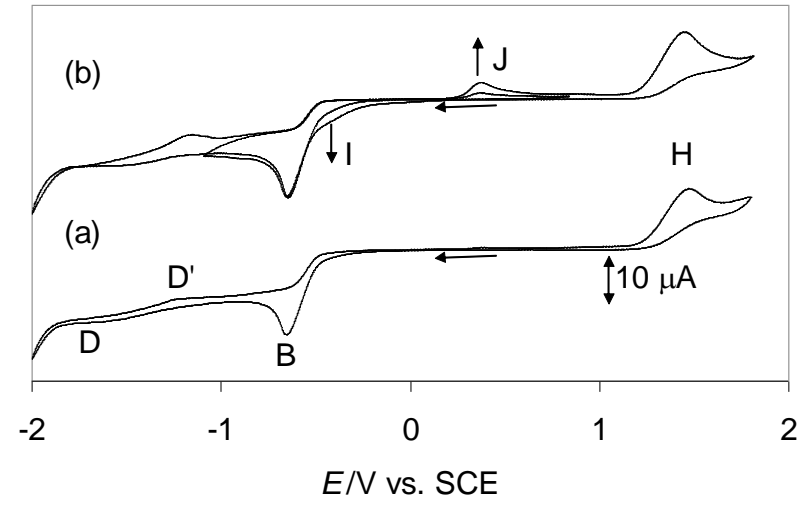

Figure 9. Cyclic voltammogram of a solution obtained upon extensive electrolysis of $\mathrm{Pd}$ (bcope) $(\mathrm{OTf})_{2}$ in $\mathrm{CH}_{2} \mathrm{Cl}_{2}$ under $\mathrm{CO}$ at $-0.5 \mathrm{~V}$ (electrolyte: $0.1 \mathrm{M}$ TBAOTf). Scan rate $=100 \mathrm{mV} / \mathrm{s}$. (a) Recorded with a freshly polished electrode. (b) Two consecutive scans recorded after scan (a).

$2[\mathrm{Pd}($ bcope $)] 2++2 \mathrm{CO}+2 \mathrm{e}-\rightarrow \quad\left[\mathrm{Pd}_{2}(\text { bcope })_{2}(\mathrm{CO})_{2}\right] 2+$

\section{Equation 6}

The voltammogram of complex $\left[\mathrm{Pd}_{2}(\text { bcope })_{2}(\mathrm{CO})_{2}\right] 2+$ is rather simple when recorded with a freshly polished electrode (Figure 9a), showing two irreversible peaks, a cathodic one with $\mathrm{E}_{\mathrm{p}, \mathrm{c}}=$ ca. $-0.66 \mathrm{~V}(\mathbf{B})$ and an anodic one with $\mathrm{E}_{\mathrm{p}, \mathrm{a}}=$ ca. $+1.50 \mathrm{~V}(\mathbf{H})$, plus small features corresponding to $\mathbf{D}$ and $\mathbf{D}^{\prime}$. The shape of the voltammogram is the same whether the scan starts in the anodic or in the cathodic direction, showing that both $\mathbf{B}$ and $\mathbf{H}$ are primary electrochemical processes of compound $\left[\mathrm{Pd}_{2}(\text { bcope })_{2}(\mathrm{CO})_{2}\right] 2+$. On the other hand, consecutive scans reveal the development of two new features - a cathodic process at ca. $-0.40 \mathrm{~V}$ (shoulder I of peak B) and an anodic one at ca. $+0.40 \mathrm{~V}$ (peak $\mathbf{J}$ ) - while at the same time the D and D' features also increased (Figure 9b). Since subsequent electrode polishing restores the voltammogram shown in Figure 9a, peaks $\mathbf{D}, \mathbf{D}^{\prime}$, $\mathbf{I}$ and $\mathbf{J}$ are attributed to 
processes involving the participation of reduced $\mathrm{Pd}$ species that deposit on the electrode surface following the reductive process B. At this point, it is useful to comment on the catalytic performance of the $\mathrm{Pd}(\mathrm{OAc})_{2} / \mathrm{L}_{2} / \mathrm{HX}$ system in olefin/CO copolymerization and on the need to add oxidants such as benzoquinone in order to improve catalytic performance. The interpretation of this phenomenon is that the active palladium catalyst can "drop out" by decomposition to $\mathrm{Pd} 0 .^{5}$ Our electrochemical experiment shows that indeed reduced species deposit on the electron surface, but only upon reducing beyond the oxidation state +1 . Carbon monoxide coordination stabilizes the PdI product, so that this is not removed as a catalyst from the system and indeed, as shown above (Equation 3) it can be reconverted into a hydride complex upon exposure to $\mathrm{H}_{2}$.

We have further carried out a coulometric reduction experiment on the isolated $\left[\mathrm{Pd}_{2}(\text { bcope })_{2}(\mathrm{CO})_{2}\right]^{2+}$, for which we measured the consumption of ca. 1.3 electrons per dinuclear complex and have measured the cyclic voltammetry of the resulting solution. However, we have not succeeded in isolating this reduction product. The reduction stoichiometry indicates that complex rearrangements follow the reduction at $\mathbf{B}$ and excludes the direct formation of a dinuclear $\mathrm{Pd}^{0}$ product which might lose ligand and precipitate. Thus, the formation of a solid deposit on the electrode must be the result of further reduction of this product. Clearly, the reductive behaviour of "Pd(bcope)(OTf)" under CO is quite complex. We did not pursue the investigation of these deep reduction products, nor of the insoluble material deposited on the electrode.

On the basis of the above coulometric and cyclic voltammetric experiments, a first mechanistic interpretation can be deduced as shown in Scheme 5. The PdII precursor does not interact with $\mathrm{CO}$. After monoelectronic reduction at $\mathbf{A}, \mathrm{CO}$ rapidly replaces the aqua ligands to yield a 1:1 adduct $[\mathrm{PdI}($ bcope $)(\mathrm{CO})]+$, which is then reduced further at $\mathbf{E}$ by a 1electron process, to yield mononuclear $\mathrm{PdO}(\mathrm{bcope})(\mathrm{CO})$. The equivalence of $\mathrm{E}_{\mathrm{E}}$ in the 
presence of the two OTf and $\mathrm{BAr}_{F}$ salts indicates a negligible ion pairing effect for the reduction of $[\mathrm{PdI}($ bcope $)(\mathrm{CO})]+$. At competitive rates, however, the mononuclear PdI complex dimerizes to yield $\left[\mathrm{PdI}_{2}(\text { bcope })_{2}(\mathrm{CO})_{2}\right] 2+$, which is reduced at $\mathrm{E}_{\mathrm{B}}$. The dependence of $E_{B}$ on the nature of the supporting electrolyte indicates stronger ion pairing for the dinuclear species, in line with its higher positive charge. Note that $E_{B}>E_{E}$, showing that dimerization facilitates the reduction process. The rapid disappearance of peak $\mathbf{A}$ in the fast, multiple scan experiment (Figure 8) indicates that the precursor PdII complex is being consumed by a chemical process involving its own reduction products generated in the diffusion layer. Among the two possibilities (product of process $\mathbf{B}$ and product of process $\mathbf{E}$ ), only the former one agrees with the data. In fact, a depletion phenomenon is also observed when the multiple scan is carried out by reversing the scan at $-0.9 \mathrm{~V}$, immediately after process $\mathbf{B}$, although the relative proximity of the $\mathbf{E}$ process does not make this evidence unambiguous. However, process $\mathbf{E} / \mathbf{E}^{\prime}$ shows electrochemical reversibility at dynamic equilibrium, excluding that the Pd0 product is engaged in a fast irreversible chemical reaction. In addition, the persistence of the $\mathbf{E} / \mathbf{E}^{\prime}$ process at dynamic equilibrium, albeit at reduced intensity, illustrates the reversibility and the counterion dependence of the dimerization process, Equation 7. On the other hand, the simultaneous observation of the $\mathbf{B}$ and $\mathbf{E}$ waves shows that the dimerization equilibrium of Equation 7 is slow on the timescale of the cyclic voltammetric experiment. The dinuclear species is favoured in all cases, but more so in the presence of the smaller trifluoroacetate counterion. This is undoubtedly another effect of ion pairing. 


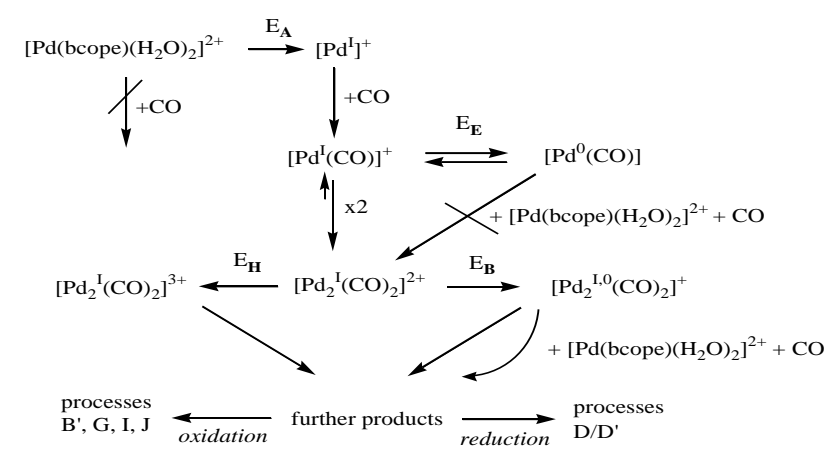

Scheme 5 Proposed mechanism for the electrochemical reduction of $[\mathrm{Pd}]^{2+}$. The bcope ligand in the reduction products is not shown for clarity.
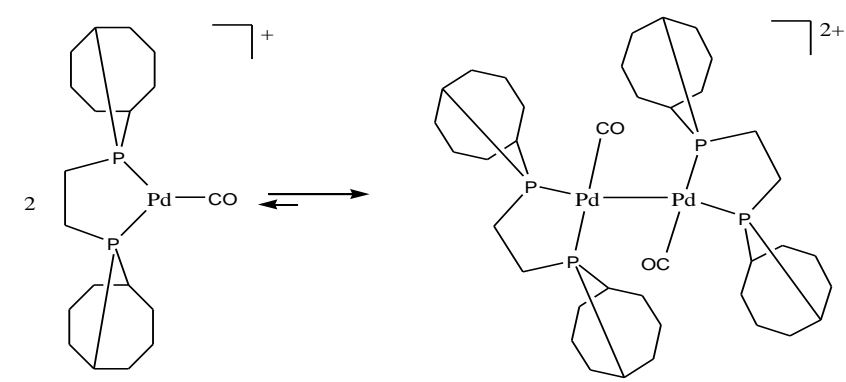

\section{Equation 7}

Further interesting information was obtained by comparing multiple scan experiments at different scan rates for the OTf and $\mathrm{BAr}_{\mathrm{F}}$ solutions. Figure 10 shows the voltammetric responses obtained with the $\mathrm{BAr}_{\mathrm{F}}$ supporting electrolyte at $50 \mathrm{mV} \mathrm{s}-1$ (a) and $200 \mathrm{mV} \mathrm{s}-1$ (b). In comparison with the corresponding scan at $1000 \mathrm{mV} \mathrm{s}-1$ (Figure 8b), the following features are worthy of note. (i) At dynamic equilibrium ( $\geq 5^{\text {th }}$ scan), peak $\mathbf{A}$ becomes more intense, relative to peak $\mathbf{B}$, at lower scan rates. This is expected because a greater amount of starting material can diffuse toward the electrode from the bulk at lower scan rates, thus compensating the amount which is consumed by the chemical reaction with the species produced at $\mathbf{B}$ during previous scans. (ii) At slower scan rates, peak $\mathbf{E}$ already shows its dynamic equilibrium intensity during the $1^{\text {st }} \mathrm{scan}$ (cf. the behaviour at $1000 \mathrm{mV} \mathrm{s}^{-1}$ in Figure $8 \mathrm{~b}$ ). This is due to the rapid dimerization process. (iii) The return peak $\mathbf{B}^{\prime}$ becomes less and less pronounced at faster scan rates. The voltammogram of complex $\left[\mathrm{Pd}_{2}(\text { bcope })_{2}(\mathrm{CO})_{2}\right]^{2+}$ (Figure 9) shows that the 
reduction process occurring at $\mathbf{B}$ is completely irreversible. Therefore, process $\mathbf{B}$ ' cannot be the reverse oxidation of the product generated at B. Moreover, if that were the case, the $\mathbf{B}^{\prime}$ peak should have a greater intensity at faster rates, contrary to what is observed. Process B' must therefore be assigned to the oxidation of another species, obtained by subsequent chemical transformation of the primary reduction product generated at $\mathbf{B}$. Such species must be generated by the interaction of the product generated at $\mathbf{B}$ and the $\mathrm{Pd}^{\mathrm{II}}$ complex that diffuses toward the electrode from the bulk. This is indicated by two independent observations: the fact that the intensity of this peak correlates with that of peak $\mathbf{A}$ at dynamic equilibrium, and the fact that no such peak $\mathbf{B}^{\prime}$ is present in the voltammogram of $\left.\left[\mathrm{Pd}_{2} \text { (bcope) }\right)_{2}(\mathrm{CO})_{2}\right]^{2+}$ (Figure 9). Therefore, this observation further confirms that the depletion of starting material from the diffusion layer results from its reaction with the product of process $\mathbf{B}$ and not with the product of process $\mathbf{E}$, as indicated in Scheme 5.

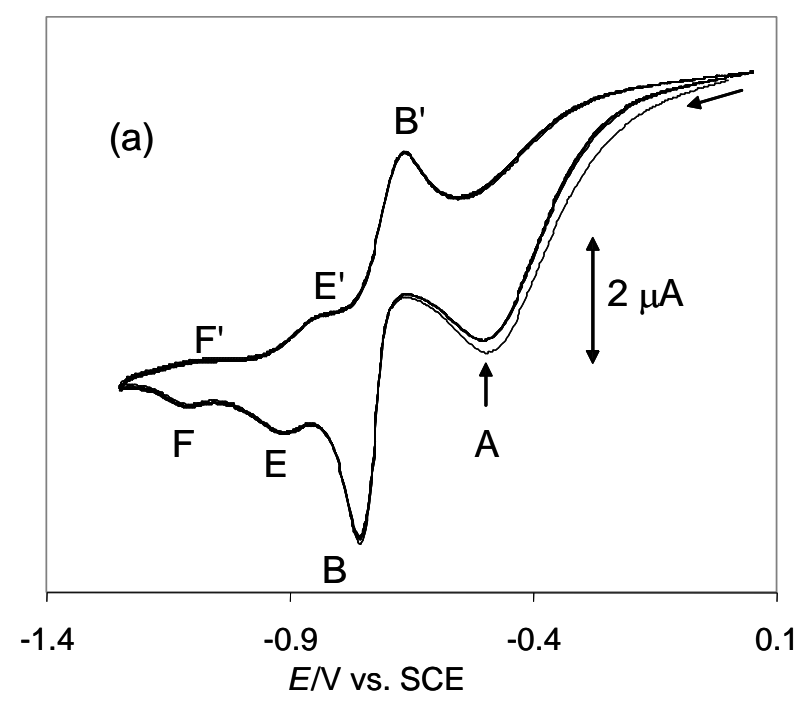




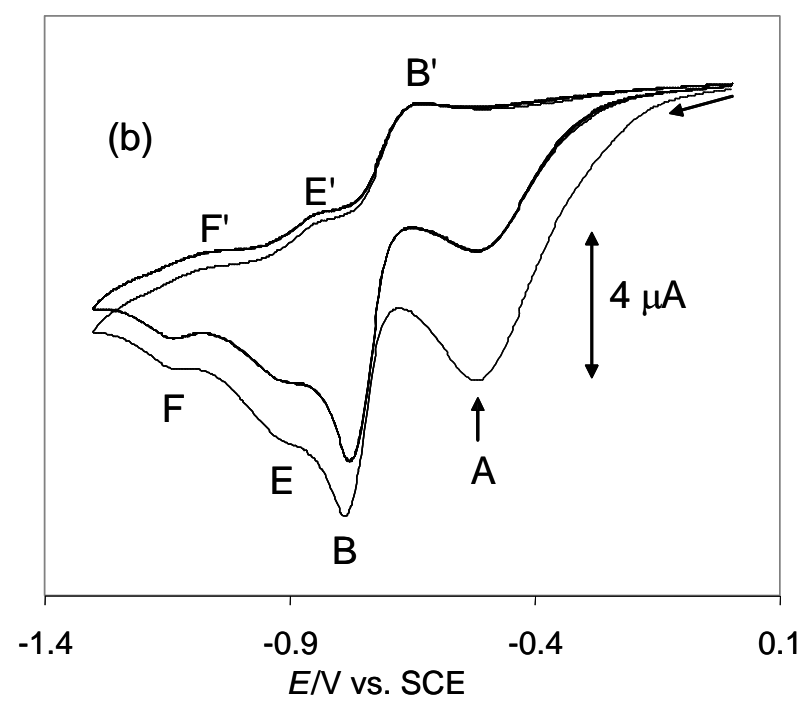

Figure 10. Five-scan cyclic voltammogram of $\mathrm{Pd}($ bcope $)(\mathrm{OTf})_{2}$ in $\mathrm{CH}_{2} \mathrm{Cl}_{2}$ under $\mathrm{CO}$ with $\operatorname{TBABAr}_{\mathrm{F}}$ as supporting electrolyte (same solution of Figure 8b). Scan rates: 50 $\mathrm{mV} \mathrm{s}^{-1}$ (a), $200 \mathrm{mV} \mathrm{s}^{-1}$ (b).

Figure 11 and Figure 12 report the results of a parallel voltammetric study as that shown above in Figure 10, except that the TBAOTf supporting electrolyte was used. Analogously to the multiple scan at $1000 \mathrm{mV} \mathrm{s}-1$ (Figure 8a), these new ones at lower speed confirm that process $\mathbf{E}$ is much less visible than for the $\mathrm{BAr}_{\mathrm{F}}$ solution. At $200 \mathrm{mV} \mathrm{s}-1$ (Figure 11), it can be clearly detected during the first scan but fades away during the following scans. The multiple scan at $50 \mathrm{mV} \mathrm{s}-1$ (Figure 12) shows yet another new interesting feature. While the intensity of peak A decreases during the initial scans, as observed previously for the BArF solution (Figure 10a), the decrease is much more pronounced and continues until the 9th scan (Figure 12a). This behaviour shows that more PdII complex diffusing towards the electrode is initially consumed by the product formed at $\mathbf{B}$, relative to the same experiment in the $\mathrm{BAr}_{\mathrm{F}}$ solution. However, after the 9th scan the trend reverses and the intensity of peak $\mathbf{A}$ increases again until a dynamic equilibrium is reached after 15 scans (Figure 12b). This phenomenon is reproducibly observed and also occurs, though at much smaller extent, in the $200 \mathrm{mV} \mathrm{s}^{-1}$ scan of Figure 11 (the intensity of peak A grows very slightly between scan 6 and 15). This behaviour may be rationalized on the basis of a rapid depletion of starting material in the 
diffusion layer while complex $\left[\mathrm{Pd}_{2}(\text { bcope })_{2}(\mathrm{CO})_{2}\right]^{2+}$ is rapidly produced and reduced at $\mathrm{E}_{\mathrm{B}}$, followed by a recovery due to diffusion from the bulk as the concentration of $\left.\left[\mathrm{Pd}_{2} \text { (bcope }\right)_{2}(\mathrm{CO})_{2}\right]^{2+}$ continues to decrease until it reaches a stationary state. We have not attempted to explore this model quantitatively by way of digital simulations, given the great complexity of the system with several unassigned electrochemical processes. A final remark about these slower rate multiple scans, in comparison with the $1000 \mathrm{mV} \mathrm{s}-1$ scan shown in Figure $8 \mathrm{a}$, is the absence of the anodic peak $\mathbf{G}$.

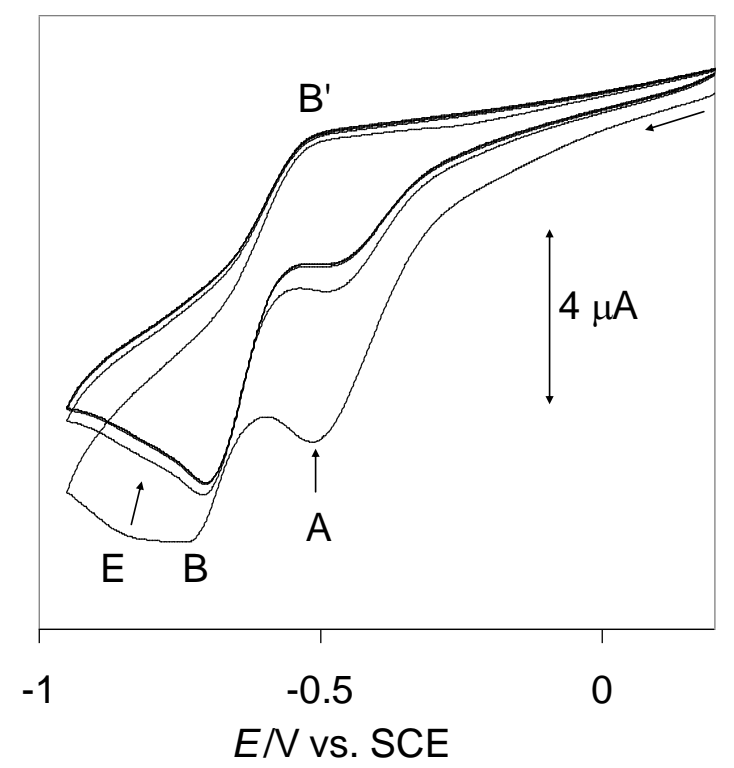

Figure 11. Multiple-scan cyclic voltammogram of $\mathrm{Pd}$ (bcope)(OTf) $)_{2}$ in $\mathrm{CH}_{2} \mathrm{Cl}_{2}$ under $\mathrm{CO}$ with TBAOTf as supporting electrolyte (same solution of Figure 8a). Scan rate: $200 \mathrm{mV} \mathrm{s}^{-1}$. 


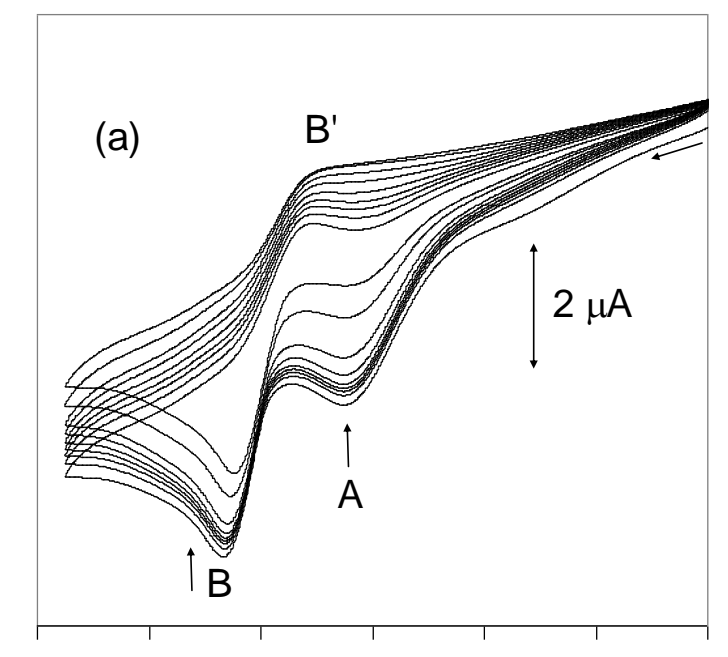

\section{$\begin{array}{lllllll}-1 & -0.8 & -0.6 & -0.4 & -0.2 & 0 & 0.2\end{array}$ $E / \mathrm{V}$ vs. SCE}

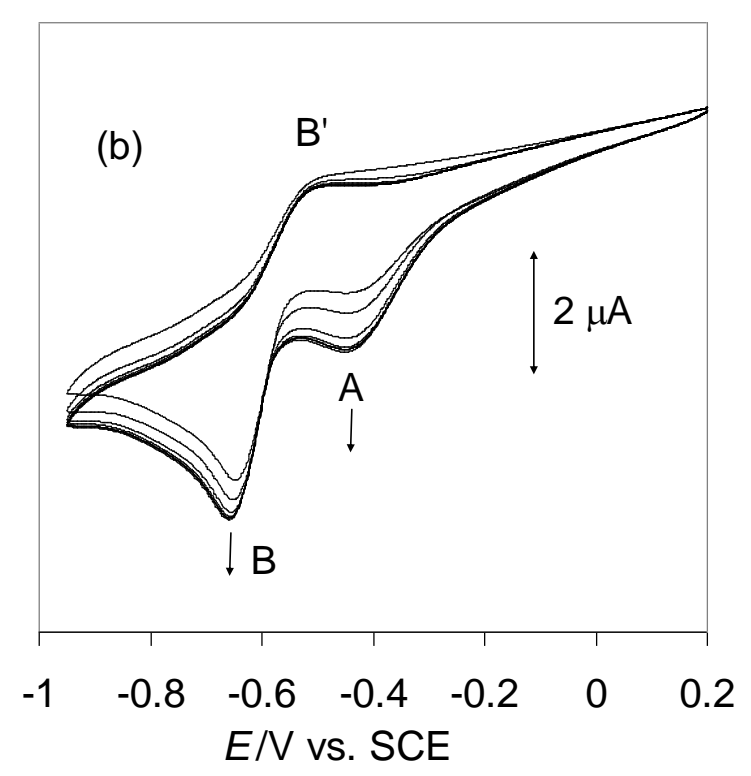

Figure 12. Multiple-scan cyclic voltammogram of $\mathrm{Pd}($ bcope $)(\mathrm{OTf})_{2}$ in $\mathrm{CH}_{2} \mathrm{Cl}_{2}$ under $\mathrm{CO}$ with $\mathrm{TBABAr}_{\mathrm{F}}$ as supporting electrolyte (same solution of Figure 8a). Scan rate: $50 \mathrm{mV} \mathrm{s}^{-1}$. Scans 1-9 (a); scans 9-15 (b).

\section{(g) Mechanistic considerations}

The collection of results from the synthetic, characterization, and electrochemical studies serves to highlight the nature of the active species for a variety of catalytic processes achieved with the " $\mathrm{L}_{2} \mathrm{PdX}_{2}$ " type of compounds, and its possible equilibria with off-loop species. It must be pointed out that the formation of compound $\mathbf{1}$ observed electrochemically 
under $\mathrm{CO}$ occurs by a combination of one-electron processes and coupled chemical events. On the other hand, only two-electron processes may occur under catalytic conditions, since the homolytic cleavage of $\mathrm{H}_{2}$ is an energetically unfavourable event. We have shown that the precursor complex reacts with $\mathrm{CO}$ only in the presence of $\mathrm{H}_{2}$ (or another reducing agent), leading to variable relative amounts of $\mathbf{1}$ and $\mathbf{2}$. These are also the major detected species at the end of all catalytic runs with "Pd(bcope)(OTf $)_{2}$ " under $\mathrm{CO} / \mathrm{H}_{2} \cdot{ }^{71}$ On the other hand, the interaction of the precursor with $\mathrm{H}_{2}$ in the absence of $\mathrm{CO}$ yields the cluster compound 3 which, in turn, yields 1 and 2 when exposed to CO. As has been previously suggested, ${ }^{5}$ the active species leading to all catalytic functions of this $\mathrm{Pd}$ system (alternating CO-olefin copolymerization, olefin hydroformylation, olefin methoxycarbonylation, etc.) is the threecoordinate $\mathrm{Pd}(\mathrm{II})$ complex $\left[\mathrm{L}_{2} \mathrm{PdH}\right]^{+}(\mathrm{L}=$ diphosphine ligand $)$ and that this species is obtained from " $\mathrm{L}_{2} \mathrm{Pd}(\mathrm{OTf})_{2}$ " by heterolytic activation of $\mathrm{H}_{2}$.

Our results can be rationalized on the basis of this suggestion, and further indicate the succession of events shown in Scheme 6. While this scheme is based on the results obtained when $\mathrm{L}_{2}=$ bcope, it is likely to have more general validity for diphosphine complexes. Since the $\mathrm{Pd}(\mathrm{II})$ starting compound does not react with $\mathrm{CO}$ in the absence of reducing agent, the first event must be the interaction with $\mathrm{H}_{2}$. This probably results in its heterolytic cleavage, as previously suggested, ${ }^{5}$ leading to the hydride complex $\left[\mathrm{L}_{2} \mathrm{PdH}\right]^{+}$, probably stabilized by water coordination, and a proton. The proton acceptor is likely to be water, which is known to be present in the starting compound, or methanol which is commonly used as solvent. These are stronger bases than the triflate anion. Therefore, the proton would be released in the form of $\left(\mathrm{ROH}_{2}\right)^{+}$. In the absence of $\mathrm{CO}$, the $\mathrm{Pd}(\mathrm{II})$ hydride species trimerizes and is deprotonated to yield compound 3 . Note that the same process may occur in the absence of water, with the triflate anion or another external base acting as proton acceptor and stabilizing the coordinatively unsaturated mononuclear hydride complex. In the presence of CO, an 
equilibrium coordination leading to square planar $\left[\mathrm{L}_{2} \mathrm{Pd}(\mathrm{CO}) \mathrm{H}\right]^{+}$may take place. The latter, in turn, may establish an equilibrium deprotonation (by water or, in its absence, triflate or other external bases) leading to a $\mathrm{Pd}^{0}$ complex, $\mathrm{L}_{2} \mathrm{Pd}(\mathrm{CO})$. Finally, combination of the two threecoordinated species $\left[\mathrm{L}_{2} \mathrm{Pd}(\mathrm{CO}) \mathrm{H}\right]^{+}$and $\mathrm{L}_{2} \mathrm{Pd}(\mathrm{CO})$ leads to the observed product 2 . It should be underlined that the trimerization of $\left[\mathrm{L}_{2} \mathrm{PdH}\right]^{+}$, leading to 3 , must be reversible as indicated in Scheme 6, since treatment of isolated $\mathbf{3}$ with CO leads to the formation of $\mathbf{2}$. The formation of 1 can be envisaged in a number of different ways. Two different pathways may originate from the reaction of mononuclear $\mathrm{L}_{2} \mathrm{Pd}(\mathrm{CO})$ with the dicationic starting complex and a second $\mathrm{CO}$ molecule, although we have shown above that this process is slow on the cyclic voltammetric time scale. The first one involves a preliminary $\mathrm{CO}$ coordination to $\mathrm{L}_{2} \mathrm{Pd}(\mathrm{CO})$, yielding a $\mathrm{L}_{2} \mathrm{Pd}(\mathrm{CO})_{2}$ intermediate, followed by collapse with the $\mathrm{Pd}^{\mathrm{II}}$ dication, whereas the second one features a preliminary interaction between the $\mathrm{Pd}^{0}$ and $\mathrm{Pd}^{\mathrm{II}}$ complexes to yield a dinuclear monocarbonyl intermediate, $\left[\mathrm{L}_{2} \mathrm{Pd}(\mu-\mathrm{CO}) \mathrm{PdL}_{2}\right]^{2+}$, which further reacts with $\mathrm{CO}$. The second possibility finds some support in our spectroscopic observation of the reversible $\mathrm{CO}$ loss from compound 1. An additional possibility, however, is that compound $\mathbf{1}$ is obtained directly from compound $\mathbf{2}$ (and vice versa) by a series of steps leading to a formal $\mathrm{H}^{-}$ / $\mathrm{CO}$ substitution. This requires the intervention of a proton source, converting $\mathrm{H}^{+}$and $\mathrm{H}^{-}$into $\mathrm{H}_{2}$, and may again involve an $\left[\mathrm{L}_{2} \mathrm{Pd}(\mu-\mathrm{CO}) \mathrm{PdL}_{2}\right]^{2+}$ intermediate. 


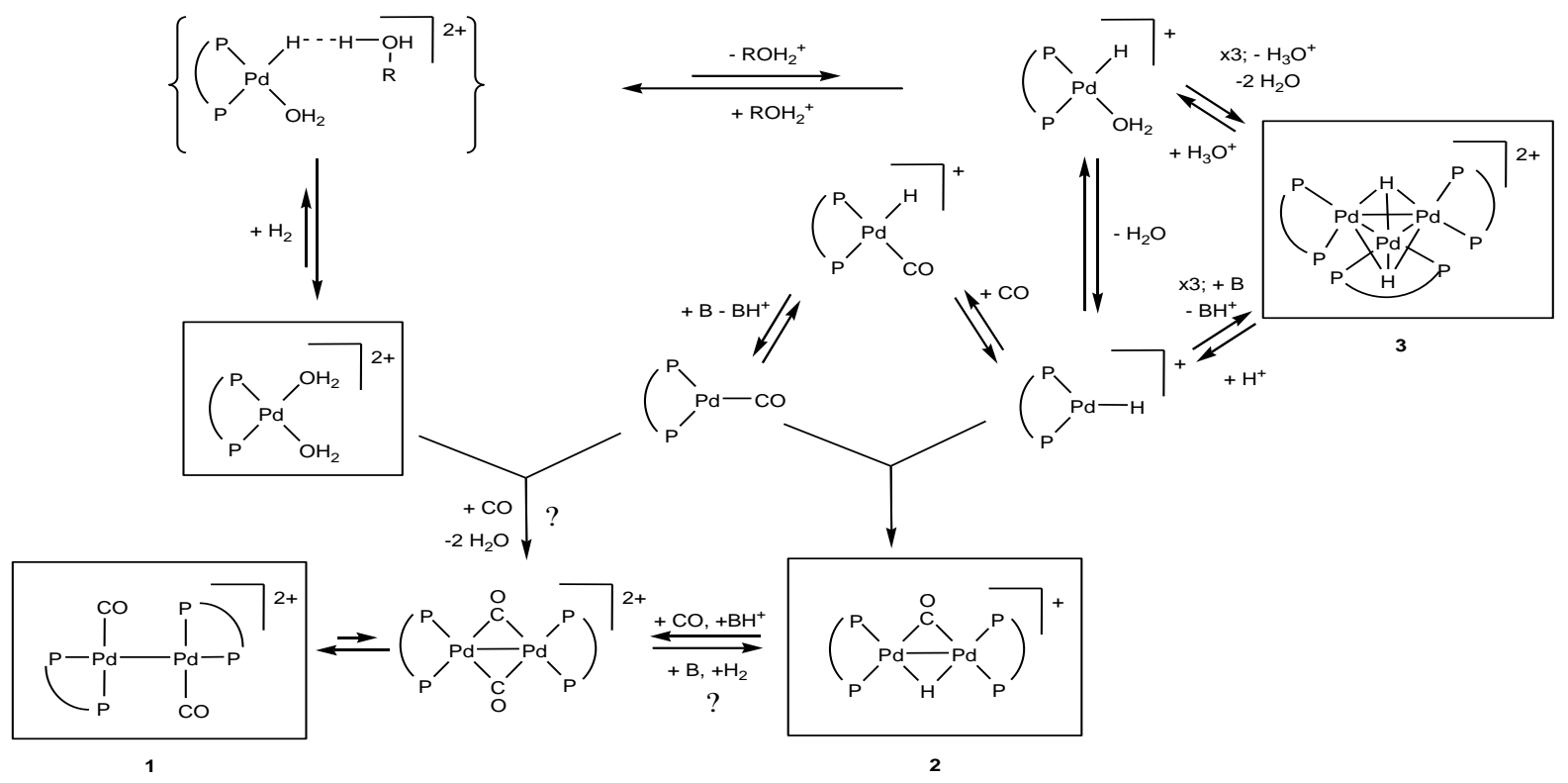

Scheme 6

\section{Conclusions}

The present investigation has brought new light on some of the fundamental processes taking place during the catalytic action of the $\mathrm{L}_{2} \mathrm{Pd}(\mathrm{OTf})_{2}$ family of compounds $\left(\mathrm{L}_{2}=\right.$ diphosphine) under syngas conditions, using the bcope ligand system as a representative example. In particular, the first examples of two previously unknown families of complexes, $\left[\left(\mathrm{L}_{2}\right)_{2} \mathrm{Pd}_{2}(\mathrm{CO})_{2}\right]^{2+}$ and $\left[\left(\mathrm{L}_{2}\right)_{3} \mathrm{Pd}_{3}(\mu-\mathrm{H})_{2}\right]^{2+}$, have been isolated and structurally characterized. These complexes ( $\mathbf{1}$ and $\mathbf{3}$, respectively, when $\mathrm{L}_{2}=$ bcope with the $\mathrm{TfO}^{-}$counterion), together with the dinuclear hydrido carbonyl compound 2, are off-loop species related to the catalytically active $\left[\mathrm{L}_{2} \mathrm{PdH}\right]^{+}{ }^{72}$

\section{Experimental section}


General. Unless otherwise stated, all operations were carried out under an atmosphere of argon using Schlenk line and glove box techniques. NMR measurements were carried out on either a Bruker AC 200 or a Bruker AMX250 spectrometer and calibrated with the residual solvent resonances $(1 \mathrm{H})$ or with external $85 \% \mathrm{H}_{3} \mathrm{PO}_{4}(31 \mathrm{P})$. The lineshape analyses for the dynamic processes were carried out by simulation with DNMR3, which is incorporated into the freely available SpinWorks program. ${ }^{73}$ The infrared spectra were recorded on a Brucker Vector 22 instrument equipped with a Globar (MIR) source. Cyclic voltammograms were measured with an EG\&G 283 potentiostat connected to a PC. The experiments were carried out in a three-electrode cell fitted with a $1.5 \mathrm{~mm}$ diameter platinum or glassy carbon disk working electrode, a platinum wire counter electrode and a BAS SCE reference electrode, separated from the analyte by a fritted bridge tube. The supporting electrolytes $\left(n \mathrm{Bu}_{4} \mathrm{~N}^{+}\right.$salts or the counterions $\mathrm{PF}_{6}{ }^{-}, \mathrm{CF}_{3} \mathrm{SO}_{3}{ }^{-}$and $\left[\mathrm{B}\left\{\mathrm{C}_{6} \mathrm{H}_{3}\left(\mathrm{CF}_{3}\right)_{2}-3,5\right\}_{4}\right]^{-}$, see text) were used at $0.2 \mathrm{M}$ concentrations. The experiments were carried out at $20^{\circ} \mathrm{C}$. All electrochemical potentials are given relative to SCE. Under identical conditions, a solution of ferrocene gave $\mathrm{E}_{1 / 2}=0.44$, 0.43 and $0.41 \mathrm{~V}$ in the presence of the $\mathrm{PF}_{6}{ }^{-}, \mathrm{CF}_{3} \mathrm{SO}_{3}{ }^{-}$and $\left[\mathrm{B}\left\{\mathrm{C}_{6} \mathrm{H}_{3}\left(\mathrm{CF}_{3}\right)_{2}-3,5\right\}_{4}\right]^{-}$supporting electrolytes, respectively. Mass spectra were obtained on a Nermag R10-10 instrument. The starting material, "Pd(bcope)(OTf)2", was obtained as previously described. ${ }^{25}$

Synthesis of $\left[\mathbf{P d} 2(\mathbf{b c o p e})_{2}(\mathbf{C O})_{2}\right](\mathbf{O T f})_{2}$, 1. A solution of $0.5 \mathrm{~g}(0.65 \mathrm{mmol})$ of $\left[\mathrm{Pd}(\right.$ bcope $\left.)\left(\mathrm{H}_{2} \mathrm{O}\right)_{2}\right](\mathrm{OTf})_{2} \cdot \mathrm{H}_{2} \mathrm{O}$ in $\mathrm{MeOH}(5 \mathrm{~mL})$ was placed under 1 bar of $\mathrm{CO} / \mathrm{H}_{2}(1: 2)$ at RT. Upon stirring for $3 \mathrm{~h}$, the initially yellow solution turned red. This solution was carefully layered with $20 \mathrm{~mL}$ of $\mathrm{Et}_{2} \mathrm{O}$. Dark red crystals formed overnight, which were isolated, washed with $\mathrm{Et}_{2} \mathrm{O}$ and dried under vacuum. Yield $154 \mathrm{mg}(40 \%)$. The compound slowly loses $\mathrm{CO}$ in the solid state unless kept under a protective CO atmosphere. Suitable analytical data could not be obtained. However, the spectroscopic properties unambiguously reveal the 
compound identity (see text) and purity. IR $\left(\mathrm{CH}_{2} \mathrm{Cl}_{2}, \mathrm{~cm}^{-1}\right): 2084$ (s), 2066 (s). ${ }^{1} \mathrm{H}$ NMR (CD ${ }_{3} \mathrm{OD}$, r.t.): $1.7-2.6$ (m, br.). ${ }^{31} \mathrm{P}$ NMR (CD $\left.3 \mathrm{OD}\right): 53.33$.

Synthesis of $\left[\mathbf{P d}_{3}(\text { bcope })_{3}\left(\mu_{3}-\mathrm{H}\right)_{2}\right](\mathbf{O T f})_{2}$, 3. $\left[\mathrm{Pd}(\right.$ bcope $\left.)\left(\mathrm{H}_{2} \mathrm{O}\right)_{2}\right](\mathrm{OTf})_{2} \cdot \mathrm{H}_{2} \mathrm{O}(555 \mathrm{mg}$, $0.72 \mathrm{mmol})$ was dissolved in methanol $(20 \mathrm{~mL})$ and the solution degassed and cooled to $-70^{\circ} \mathrm{C}$. A solution of dimethylphenylsilane $\left(\mathrm{PhMe}_{2} \mathrm{SiH} ; 232 \mathrm{mg}, 1.7 \mathrm{mmol}\right)$ in methanol (1 $\mathrm{mL}$ ) was added dropwise and stirring was continued for $5 \mathrm{~min}$ to give a dark green/brown solution. Stirring was stopped and the solution was allowed to warm to room temp. Upon standing green/brown crystals appeared which were isolated, washed with methanol and dried under vacuum. Yield $0.43 \mathrm{~g}, 80 \%$. One single crystal was selected for the X-ray analysis. ${ }^{1} \mathrm{H}$ NMR $\left(\mathrm{CD}_{2} \mathrm{Cl}_{2}\right): \delta-6.53\left(\right.$ sept, $\left.2 \mathrm{H}, \mathrm{J}_{\mathrm{PH}}=36.9 \mathrm{~Hz}\right), 1.0-3.5(\mathrm{~m}, 96 \mathrm{H}) .{ }^{31} \mathrm{P}\left\{{ }^{1} \mathrm{H}\right\} \mathrm{NMR}$ $\left(\mathrm{CD}_{2} \mathrm{Cl}_{2}\right): \delta$ 52.74. Anal. Calcd. (found) for $\mathrm{C}_{56} \mathrm{H}_{98} \mathrm{~F}_{6} \mathrm{O}_{6} \mathrm{P}_{6} \mathrm{Pd}_{3} \mathrm{~S}_{2}: \mathrm{C}, 43.38$ (43.19); H, 6.37 (6.52)\%. MS (FAB, MNBA): $m / z(\%) 1401(0.48)$ [M - OTf]; 1250 (7.0) [M - 2OTf - 2H]; $833(100)\left[\mathrm{Pd}_{2}(\text { bcope })_{2}-\mathrm{H}\right] ; 415$ (33.4) [Pd(bcope) - H].

\section{Formation and isolation of $\left[\mathrm{Pd}_{2}\left(\right.\right.$ bcope $\left._{2}(\mu-\mathrm{CO})(\mu-\mathrm{H})\right](\mathrm{OTf}), 2$}

A suspension of compound 3 (350 mg, $0.19 \mathrm{mmol})$ in "SWET" $(10 \mathrm{~mL})^{29}$ was placed under $\mathrm{CO}$ (2 bars) at room temp. The color of the solution changed from dark brown to orange red within seconds. After stirring for $2 \mathrm{~h}$, diethyl ether $(10 \mathrm{~mL})$ was layered carefully on top of the solution. Over a period of 2 days crystals formed which were separated and characterized as the by-product $\left[\mathrm{Pd}_{2}(\text { bcope })_{2}(\mathrm{CO})_{2}\right](\mathrm{OTf})_{2}, 1$. More diethyl ether was layered on top of the supernatant and the dark red crystals of compound $\mathbf{2}$ which formed were isolated, washed with diethyl ether and dried under vacuum. Yield 20\%. ${ }^{1} \mathrm{H} \mathrm{NMR}\left(\mathrm{CD}_{2} \mathrm{Cl}_{2}\right)$ : $\delta-5.50$ (quintet, $1 \mathrm{H} \mathrm{J} \mathrm{HP}=46.9 \mathrm{~Hz}), 1.8-3.0(\mathrm{~m}, 64 \mathrm{H}) ;{ }^{31} \mathrm{P}\left\{{ }^{1} \mathrm{H}\right\} \mathrm{NMR}\left(\mathrm{CD}_{2} \mathrm{Cl}_{2}\right): \delta$ 19.0. IR $\left(\mathrm{CH}_{2} \mathrm{Cl}_{2}, \mathrm{v}\right): 1818(\mathrm{~m}) \mathrm{cm}^{-1}$. No microanalytical data were obtained on this compound; the spectroscopic properties unambiguously reveal the compound identity (see text) and purity. 
Electrochemistry. Voltammetric measurements were carried out with an Autolab PGSTAT100 potentiostat. Experiments were carried out at room temperature in a homemade airtight three-electrode cell connected to a vacuum/argon line. The reference electrode consisted of a saturated calomel electrode (SCE) separated from the solution by a bridge compartment. The counter electrode was a platinum wire of ca $1 \mathrm{~cm}^{2}$ apparent surface. The working electrode was a $\mathrm{Pt}$ microdisk (1mm diameter). The supporting electrolytes $\left(n \mathrm{Bu}_{4} \mathrm{~N}\right)\left[\mathrm{PF}_{6}\right]$ (Fluka, 99\% electrochemical grade) and $n \mathrm{Bu}_{4} \mathrm{NCF}_{3} \mathrm{SO}_{3}$ (Aldrich, 99\%) were used as received. The supporting electrolyte $n \mathrm{Bu}_{4} \mathrm{~N}\left[\mathrm{~B}\left\{\mathrm{C}_{6} \mathrm{H}_{3}\left(\mathrm{CF}_{3}\right)_{2}-3,5\right\}_{4}\right]$ was synthesized by ion metathesis from commercially available $\mathrm{Li}\left[\mathrm{B}\left\{\mathrm{C}_{6} \mathrm{H}_{3}\left(\mathrm{CF}_{3}\right)_{2}-3,5\right\}_{4}\right]$, as described in the literature. ${ }^{74}$ Dichloromethane was freshly distilled over Na/benzophenone prior to use. The solutions used during the electrochemical studies were $3.5 \cdot 10^{-3} \mathrm{M}$ in palladium compound and 0.1 $\mathrm{M}$ in supporting electrolyte. Before each measurement, the solutions were degassed by bubbling Ar or $\mathrm{CO}$ and the working electrode was polished with a polishing machine (Presi P230). All potentials are reported versus the SCE. The reversible wave of ferrocene appears at $0.455 \mathrm{~V}\left(0.1 \mathrm{M} \mathrm{TBAPF}_{6}\right)$ under the same conditions. Controlled-potential electrolyses were carried out in a three electrode cell with a Pt gauze working electrode $\left(\mathrm{ca} 7 \mathrm{~cm}^{2}\right)$, reference and counter electrodes separated by two glass frits.

X-ray crystallography. A single crystal of each compound was mounted under inert perfluoropolyether at the tip of glass fibre and cooled in the cryostream of an OxfordDiffraction XCALIBUR CCD diffractometer for $\left[\mathrm{Pd}_{2}(\text { bcope })_{2}(\mathrm{CO})_{2}\right](\mathrm{OTf})_{2}$ and $\mathrm{Pd}($ bcope $)(\mathrm{OTf})_{2}$ or a Bruker SMART diffractometer for $\left[\mathrm{Pd}_{3}(\text { bcope })_{3} \mathrm{H}_{2}\right](\mathrm{OTF})_{2}$. Data were collected using the monochromatic $\mathrm{MoK}_{\alpha}$ radiation $(\lambda=0.71073)$. The structures were solved by direct methods (SIR97) $)^{75}$ and refined by least-squares procedures on $F^{2}$ using SHELXL97. ${ }^{76}$ All $\mathrm{H}$ atoms attached to carbon were introduced in idealised positions and treated with the riding model. In compound $\left[\mathrm{Pd}_{2}(\mathrm{bcope})_{2}(\mathrm{CO})_{2}\right](\mathrm{OTf})_{2}$, the ethylene backbone 
of one bcope ligand is disordered over two positions. This disorder was treated using the tools available in SHELXL97. ${ }^{76}$ In compound $\left[\mathrm{Pd}_{3}(\text { bcope })_{3} \mathrm{H}_{2}\right](\mathrm{OTF})_{2}$, one of the trinuclear $\mathrm{Pd}$ complex is fully disordered around the $00 \mathrm{z}$ three fold axis whereas the second one is well defined and located around $1 / 32 / 3 \mathrm{z}$ (or $2 / 31 / 3 \mathrm{z}$ ). Owing to this unusual disorder and to a Flack parameter ${ }^{77,78}$ with value of $0.20(8)$, the occurrence of possible twinning by merohedry (or pseudo-merohedry) was considered but not found to improve the model. Attempt to solve and refine the structure in the possible subgroups trigonal $\mathrm{P} 3$ or monoclinic $\mathrm{P} 2{ }_{1}$ did not lead to an improved refinement. Although the structure could be solved and refined in either of these space groups, one of the trinuclear Pd complex ions remained disordered. Therefore, the refinement in $\mathrm{P}_{3}$ was used for the final cycles of refinement considering a possible twin by inversion (racemic twin) to explain the value of the Flack parameter. Finally, some residual electron density derived from included solvent proved impossible to model using distinct atomic sites. Therefore, the SQUEEZE function of PLATON ${ }^{79}$ was used to eliminate the contribution of the electron density in the solvent region from the intensity data and the solvent-free model was employed for the final refinement. PLATON estimated that the cavity within the cell contains 83 electrons, which would correspond to approximately four methanol molecules (the solvent used for crystallization). Although there is no doubt about the identity and the gross geometry of the trinuclear Pd complex ion nor of the stoichiometry of the compound, the quality of the refinement is rather low and none of the hydride $\mathrm{H}$ atoms could be located. A doubt remains as to the validity of the space group used for the refinement even if no other space group could be reasonably defined. The drawing of the molecules was realised using ORTEP $32{ }^{80}$ Crystal data and refinement parameters are shown in Table 3. Crystallographic data (excluding structure factors) have been deposited with the Cambridge Crystallographic Data Centre as supplementary publication no. CCDC 679000-679002. Copies of the data can be obtained free of charge on application to the Director, CCDC, 12 
Union Road, Cambridge CB2 1EZ, UK (fax: (+44) 1223-336-033; e-mail: deposit@ccdc.cam.ac.uk).

Table 3. Crystal data and structure refinement parameters for all X-ray structures.

\begin{tabular}{|c|c|c|c|}
\hline Identification code & {$\left[\mathrm{Pd}(\right.$ bcope $\left.)\left(\mathrm{H}_{2} \mathrm{O}\right)_{2}\right](\mathrm{OTf})_{2} \cdot \mathrm{H}_{2} \mathrm{O}$} & {$\left[\mathrm{Pd}_{2}(\mathrm{bcope})_{2}(\mathrm{CO})_{2}\right](\mathrm{OTf})_{2}$} & {$\left[\mathrm{Pd}_{3}(\text { bcope })_{3} \mathrm{H}_{2}\right](\mathrm{OTF})_{2}$} \\
\hline Empirical formula & $\mathrm{C}_{40} \mathrm{H}_{66} \mathrm{~F}_{12} \mathrm{O}_{17} \mathrm{P}_{4} \mathrm{Pd}_{2} \mathrm{~S}_{4}$ & $\mathrm{C}_{40} \mathrm{H}_{64} \mathrm{~F}_{6} \mathrm{O}_{8} \mathrm{P}_{4} \mathrm{Pd}_{2} \mathrm{~S}_{2}$ & $\mathrm{C}_{56} \mathrm{H}_{96} \mathrm{~F}_{6} \mathrm{O}_{6} \mathrm{P}_{6} \mathrm{Pd}_{3} \mathrm{~S}_{2}$ \\
\hline Formula weight & 1511.85 & 1033.34 & 1550.47 \\
\hline Temperature, $\mathrm{K}$ & $180(2) \mathrm{K}$ & $180(2) \mathrm{K}$ & $173(2)$ \\
\hline Wavelength, $\AA$ & $0.71073 \AA$ & $0.71073 \AA$ & 0.71073 \\
\hline Crystal system & Monoclinic & Monoclinic & Trigonal \\
\hline Space group & $\mathrm{C} 2 / \mathrm{c}$ & $\mathrm{P} 2{ }_{1} / \mathrm{c}$ & $\mathrm{P} 6_{3}$ \\
\hline a, $\AA$ & $44.5742(18)$ & $17.3241(6)$ & $23.452(3)$ \\
\hline $\mathrm{b}, \AA$ & $11.3560(7)$ & $13.0746(6)$ & $23.452(3)$ \\
\hline $\mathrm{c}, \AA$ & $23.1131(12)$ & $21.2901(8)$ & $10.6808(15)$ \\
\hline$\alpha,{ }^{\circ}$ & 90.0 & 90.0 & 90.0 \\
\hline$\beta,^{\circ}$ & $100.165(4)$ & $100.834(3)$ & 90.0 \\
\hline$\gamma,{ }^{\circ}$ & 90.0 & 90.0 & 120.0 \\
\hline $\mathrm{V}, \AA^{3}$ & $11515.8(10)$ & $4736.4(3)$ & $5087.4(11)$ \\
\hline $\mathrm{Z}$ & 8 & 4 & 3 \\
\hline Dcalc, $\mathrm{Mg} / \mathrm{m}^{3}$ & 1.744 & 1.449 & 1.759 \\
\hline$\mu, \mathrm{mm}^{-1}$ & 0.984 & 1.044 & 1.106 \\
\hline $\mathrm{F}(000)$ & 6128 & 2048 & 2772 \\
\hline Crystal size, $\mathrm{mm}^{3}$ & $0.63 \times 0.39 \times 0.15$ & $0.67 \times 0.53 \times 0.38$ & $0.62 \times 0.12 \times 0.09$ \\
\hline$\theta^{\circ}$, range & 2.79 to 26.37 & 3.16 to 26.37 & 1.74 to 24.99 \\
\hline Reflect. coll. & 43903 & 33348 & 26852 \\
\hline Unique reflect. [Rint] & $11769[0.0525]$ & $9655[0.0288]$ & $5829[0.0865]$ \\
\hline Absorption correction & Multi-scan & Multi-scan & Multi-scan \\
\hline Max. / min. transm. & $0.8313 / 0.6565$ & $1.000 / 0.919$ & 0.862090 and 0.411857 \\
\hline Refinement method & $\mathrm{F}^{2}$ & $\mathrm{~F}^{2}$ & $\mathrm{~F}^{2}$ \\
\hline Data/restr./param. & $11769 / 12 / 736$ & $9655 / 5 / 577$ & 5829 / 493 / 452 \\
\hline GOF on $\mathrm{F}^{2}$ & 1.063 & 1.080 & 1.106 \\
\hline $\mathrm{R} 1, w R 2[\mathrm{I}>2 \sigma(\mathrm{I})]$ & $0.0489,0.1254$ & $0.0509,0.1150$ & $0.0752,0.1853$ \\
\hline R1, wR2 (all data) & $0.0666,0.1374$ & $0.0577,0.1203$ & $0.0888,0.1907$ \\
\hline Flack parameter & & & $0.20(8)$ \\
\hline Largest diff. $\Delta \mathrm{e}, \mathrm{e}^{-3}$ & $1.689 /-0.995$ & $2.040 /-0.788$ & $1.109 /-1.263$ \\
\hline
\end{tabular}

Computational details. QM calculations were performed with the Gaussian03 package $^{81}$ at the DFT-B3LYP level. ${ }^{82-84}$ The BCOPE diphosphine ligand was simplified to $\mathrm{H}_{2} \mathrm{PCH}_{2} \mathrm{CH}_{2} \mathrm{PH}_{2}$ (DHPE). For the Pd atom, the LANL2DZ pseudopotential ${ }^{85}$ was used with the addition of $\mathrm{f}$ polarization functions. ${ }^{86}$ Carbon, oxygen and phosphorous atoms were described with a 6-31G* set of basis functions, whereas hydrogen atoms were described with a 6-31G basis set. Minima and transition state were characterized by analytically computing 
the Hessian matrix. Information on absolute energies and atom coordinates (xyz files) for all optimized structures is collected in the supplementary material.

\section{Acknowledgment}

We thank the European Commission through the HYDROCHEM program (contract HPRN CT-2002-00176) for support of this work. MB thanks the Spanish Ministerio de Educación y Ciencia for a post-doctoral fellowship and the Spanish MEC/Universidad de Zaragoza for funding through the "Ramón y Cajal" program. We are grateful to Dr. Alix Sournia-Saquet for the electrochemical measurements.

\section{Supporting Information}

Crystallographic details ( $\mathrm{H}$ bonding, packing diagram) for compound $\left[\mathrm{Pd}(\right.$ bcope $\left.)\left(\mathrm{H}_{2} \mathrm{O}\right)_{2}\right](\mathrm{OTf})_{2} \cdot \mathrm{H}_{2} \mathrm{O} ;$ optimized geometries for the model system of the $\left[\mathrm{Pd}_{2}(\text { bcope })_{2}(\mathrm{CO})_{2}\right]^{2+}$ complex.

\section{References}

1 Tsuji, J.; Editor, Perspectives in Organopalladium Chemistry for the XXI Century. ed.; 1999.

2 Tsuji, J., Transition Metal Reagents and Catalysts: Innovations in Organic Synthesis. ed.; 2000 .

3 Tsuji, J.; Editor, Palladium in Organic Synthesis. ed.; 2005.

$4 \quad$ Sen, A., Adv. Polym. Sci. 1986, 73-74, 125-44.

5 Drent, E.; Budzelaar, P. H. M., Chem. Rev. 1996, 96, 663-81.

6 Durand, J.; Milani, B., Coord. Chem. Rev. 2006, 250, 542-560.

7 Binotti, B.; Bellachioma, G.; Cardaci, G.; Carfagna, C.; Zuccaccia, C.; Macchioni, A., Chem. Eur. J. 2007, 13, 1570-1582.

8 Drent, E.; Budzelaar, P. H. M., J. Organometal. Chem. 2000, 593-594, 211-225.

$9 \quad$ Konya, D.; Lenero, K. Q. A.; Drent, E., Organometallics 2006, 25, 3166-3174.

10 Brumbaugh, J. S.; Whittle, R. R.; Parvez, M.; Sen, A., Organometallics 1990, 9, 1735 47.

11 Ozawa, F.; Hayashi, T.; Koide, H.; Yamamoto, A., J. Chem. Soc., Chem. Commun. 1991, 1469-70. 
Markies, B. A.; Rietveld, M. H. P.; Boersma, J.; Spek, A. L.; Van Koten, G., J. Organomet. Chem. 1992, 424, C12-C16.

Batistini, A.; Consiglio, G., Organometallics 1992, 11, 1766-1769.

Dekker, G. P. C. M.; Elsevier, C. J.; Vrieze, K.; Van Leeuwen, P. W. N. M.; Roobeek, C. F., J. Organomet. Chem. 1992, 430, 357-372.

Van Leeuwen, P. W. N. M.; Roobeek, C. F.; Van Der Heijden, H., J. Am. Chem. Soc. 1994, 116, 12117-18.

Van Asselt, R.; Gielens, E.; Rulke, R. E.; Vrieze, K.; Elsevier, C. J., J. Am. Chem. Soc. 1994, 116, 977-985.

Markies, B. A.; Kruis, D.; Rietveld, M. H. P.; Verkerk, K. A. N.; Boersma, J.;

Kooijman, H.; Lakin, M. T.; Spek, A. L.; Van Koten, G., J. Am. Chem. Soc. 1995, 117, 5263-74.

Carfagna, C.; Formica, M.; Gatti, G.; Musco, A.; Pierleoni, A., Chem. Commun. 1998, 1113-1114.

Binotti, B.; Carfagna, C.; Gatti, G.; Martini, D.; Mosca, L.; Pettinari, C., Organometallics 2003, 22, 1115-1123.

Barlow, G. K.; Boyle, J. D.; Cooley, N. A.; Ghaffar, T.; Wass, D. F., Organometallics 2000, 19, 1470-1476.

Zuccaccia, C.; Bellachioma, G.; Cardaci, G.; Macchioni, A.; Binotti, B.; Carfagna, C., Helv. Chim. Acta 2006, 89, 1524-1546.

Carfagna, C.; Gatti, G.; Mosca, L.; Paoli, P.; Guerri, A., Helv. Chim. Acta 2006, 89, $1660-1671$.

Liu, J.; Heaton, B. T.; Iggo, J. A.; Whyman, R.; Bickley, J. F.; Steiner, A., Chem. Eur. J. 2006, 12, 4417-4430.

Bianchini, C.; Meli, A.; Oberhauser, W.; Claver, C.; Garcia Suarez, E. J., Eur. J. Inorg. Chem. 2007, 2702-2710.

Lopez-Serrano, J.; Duckett, S. B.; Aiken, S.; Almeida Lenero, K. Q.; Drent, E.;

Dunne, J. P.; Konya, D.; Whitwood, A. C., J. Am. Chem. Soc. 2007, 129, 6513-6527.

Lloyd, B. R.; Manojlovicmuir, L.; Muir, K. W.; Puddephatt, R. J., Organometallics

1993, 12, 1231-1237.

Budzelaar, P. H. M.; Van Leeuwen, P. W. N. M.; Roobeek, C. F.; Orpen, A. G., Organometallics 1992, 11, 23-5.

Portnoy, M.; Frolow, F.; Milstein, D., Organometallics 1991, 10, 3960-3962.

SWET is an acronym used at Shell for a solvent mixture composed of: sulfolane (15\% $\mathrm{wt})$, water (1\% wt), ethanol (28\% wt), and toluene-d 8 (56\% wt).

Fryzuk, M. D.; Lloyd, B. R.; Clentsmith, G. K. B.; Rettig, S. J., J. Am. Chem. Soc. 1994, 116, 3804-3812.

Kirss, R. U.; Eisenberg, R., Inorg. Chem. 1989, 28, 3372-8.

Gauthron, I.; Gagnon, J.; Zhang, T.; Rivard, D.; Lucas, D.; Mugnier, Y.; Harvey, P. D., Inorg. Chem. 1998, 37, 1112-1115.

Meilleur, D.; Rivard, D.; Harvey, P. D.; Gauthron, I.; Lucas, D.; Mugnier, Y., Inorg. Chem. 2000, 39, 2909-2914.

Cugnet, C.; Mugnier, Y.; Dal Molin, S.; Brevet, D.; Lucas, D.; Harvey, P. D., Inorg. Chem. 2007, 46, 3083-3088.

Ramachandran, R.; Payne, N. C.; Puddephatt, R. J., J. Chem. Soc., Chem. Comm. 1989, 128-9.

Ramachandran, R.; Puddephatt, R. J., Inorg. Chem. 1993, 32, 2256-60.

Lin, W.; Wilson, S. R.; Girolami, G. S., Inorg. Chem. 1994, 33, 2265-72.

Tanase, T.; Kawahara, K.; Ukaji, H.; Kobayashi, K.; Yamazaki, H.; Yamamoto, Y., Inorg. Chem. 1993, 32, 3682-8. 
Tanase, T.; Takahata, H.; Hasegawa, M.; Yamamoto, Y., J. Organomet. Chem. 1997, 545-546, 531-541.

Yamamoto, Y.; Fukui, Y.; Matsubara, K.; Takeshima, H.; Miyauchi, F.; Tanase, T.; Yamamoto, G., J. Chem. Soc., Dalton Trans. 2001, 1773-1781.

Wilson, W. L.; Nelson, J. H.; Alcock, N. W., Organometallics 1990, 9, 1699-700.

Song, H.-B.; Zhang, Z.-Z.; Mak, T. C. W., Inorg. Chem. Commun. 2002, 5, 442-445. Browning, C. S.; Farrar, D. H.; Frankel, D. C.; Vittal, J. J., Inorg. Chim. Acta 1997, 254, 329-338.

Dubois, D. L.; Miedaner, A.; Haltiwanger, R. C., J. Am. Chem. Soc. 1991, 113, $8753-$ 64.

Christmann, U.; Pantazis, D. A.; Benet-Buchholz, J.; Mcgrady, J. E.; Maseras, F.; Vilar, R., Organometallics 2006, 25, 5990-5995.

Fryzuk, M. D.; Clentsmith, G. K. B.; Rettig, S. J., J. Chem. Soc., Dalton Trans. 1998, 2007-2016.

Trebbe, R.; Goddard, R.; Rufinska, A.; Seevogel, K.; Poerschke, K.-R., Organometallics 1999, 18, 2466-2472.

Mednikov, E. G.; Eremenko, N. K.; Mikhailov, V. A.; Gubin, S. P.; Slovokhotov, Y. L.; Struchkov, Y. T., J. Chem. Soc., Chem. Comm. 1981, 989-90.

Dubrawski, J.; Kriege-Simondsen, J. C.; Feltham, R. D., J. Am. Chem. Soc. 1980, 102, 2089-91.

Mednikov, E. G.; Eremenko, N. K.; Gubin, S. P.; Slovokhotov, Y. L.; Struchkov, Y. A., J. Organomet. Chem. 1982, 239, 401-16.

Goddard, R.; Jolly, P. W.; Krueger, C.; Schick, K. P.; Wilke, G., Organometallics 1982, 1, 1709-12.

Manojlovic-Muir, L.; Muir, K. W.; Lloyd, B. R.; Puddephatt, R. J., J. Chem. Soc., Chem. Comm. 1983, 1336-7.

Provencher, R.; Aye, K. T.; Drouin, M.; Gagnon, J.; Boudreault, N.; Harvey, P. D., Inorg. Chem. 1994, 33, 3689-99.

Holah, D. G.; Hughes, A. N.; Krysa, E.; Spivak, G. J.; Havighurst, M. D.; Magnuson, V. R., Polyhedron 1997, 16, 2353-2359.

Lemaitre, F.; Lucas, D.; Groison, K.; Richard, P.; Mugnier, Y.; Harvey, P. D., J. Am. Chem. Soc. 2003, 125, 5511-5522.

Moiseev, I. I.; Stromnova, T. A.; Vargaftig, M. N.; Mazo, G. J.; Kuz'mina, L. G.; Struchkov, Y. T., J. Chem. Soc., Chem. Comm. 1978, 27-8. Jennings, M. C.; Payne, N. C.; Puddephatt, R. J., Inorg. Chem. 1987, 26, 3776-3781. Douglas, G.; Jennings, M. C.; Manojlovic-Muir, L.; Muir, K. W.; Puddephatt, R. J., J. Chem. Soc., Chem. Comm. 1989, 159-61.

Bradford, A. M.; Douglas, G.; Manojlovicmuir, L.; Muir, K. W.; Puddephatt, R. J., Organometallics 1990, 9, 409-416.

Schoettel, G.; Vittal, J. J.; Puddephatt, R. J., J. Am. Chem. Soc. 1990, 112, 6400-6402. Manojlovic-Muir, L.; Muir, K. W.; Rashidi, M.; Schoettel, G.; Puddephatt, R. J., Organometallics 1991, 10, 1719-1727.

Jennings, M. C.; Schoettel, G.; Roy, S.; Puddephatt, R. J., Organometallics 1991, 10, 580-6.

Lucas, D.; Lemaitre, F.; Gallego-Gomez, B.; Cugnet, C.; Richard, P.; Mugnier, Y.; Harvey, P. D., Eur. J. Inorg. Chem. 2005, 1011-1018.

Brevet, D.; Lucas, D.; Richard, P.; Vallat, A.; Mugnier, Y.; Harvey, P. D., Can. J. Chem. 2006, 84, 243-250.

Carmichael, D.; Hitchcock, P. B.; Nixon, J. F.; Pidcock, A., Chem. Commun. 1988, 1554-1556. 
Ramachandran, R.; Yang, D. S.; Payne, N. C.; Puddephatt, R. J., Inorg. Chim. Acta 1991, 186, 1-3.

Ramachandran, R.; Yang, D. S.; Payne, N. C.; Puddephatt, R. J., Inorg. Chem. 1992, 31, 4236-4240.

Barriere, F.; Geiger, W. E., J. Am. Chem. Soc. 2006, 128, 3980-3989.

Brownie, J. H.; Baird, M. C.; Laws, D. R.; Geiger, W. E., Organometallics 2007, 26, 5890-5901.

Chong, D.; Laws, D. R.; Nafady, A.; Costa, P. J.; Rheingold, A. L.; Calhorda, M. J.; Geiger, W. E., J. Am. Chem. Soc. 2008, 130, 2692-2703.

Other species present are $\left[\mathrm{Pd}(\text { bcope })_{2}\right](\mathrm{OTf})_{2}(20-30 \%)$, presumed to result from some catalyst degradation with liberation of free ligand, and complexes of type $\left[\mathrm{Pd}(\mathrm{bcope})(\right.$ allyl) $](\mathrm{OTf})_{2}$ (ca. 20\%), assumed to result from a reaction of the catalyst (in hydridic form, so as $[\mathrm{Pd}($ bcope $) \mathrm{H}](\mathrm{OTf})$ ) with the small amount of dienes present in the olefin feed: L. Schoon, W. P. Mul, A. B. van Oort, N. Meijboom, unpublished observations.

The reduced complex $\mathbf{1}$ was tested under same conditions as normal catalysis (using the $\mathrm{Pd}^{\mathrm{II}}$ precatalyst), yielding a remarkably similar catalytic activity: W. P. Mul, L. Schoon, A. B. van Oort, N. Meijboom, unpublished observations.

Marat, K., SpinWorks Version 2.5.4. ed.; 2006.

Lesuer, R. J.; Buttolph, C.; Geiger, W. E., Anal. Chem. 2004, 76, 6395-6401.

Altomare, A.; Burla, M.; Camalli, M.; Cascarano, G.; Giacovazzo, C.; Guagliardi, A.; Moliterni, A.; Polidori, G.; Spagna, R., J. Appl. Cryst. 1999, 32, 115-119.

Sheldrick, G. M., SHELXL97. Program for Crystal Structure refinement. ed.;

University of Göttingen: Göttingen, Germany, 1997.

Flack, H. D., Acta Cryst. 1983, A39, 876-881.

Bernardinelli, G.; Flack, H. D., Acta Cryst., Sect A 1985, 41, 500-511.

Van Der Sluis, P.; Spek, A. L., Acta Crystallogr., Sect. A: Found. Cryst. 1990, 46, 194-201.

Farrugia, L. J., J. Appl. Crystallogr. 1997, 32, 565.

Frisch, M. J., et al., Gaussian 03, Revision B.05. ed.; Gaussian, Inc.: Wallingford CT, 2004.

Becke, A. D., J. Chem. Phys. 1993, 98, 5648-5652.

Lee, C. T.; Yang, W. T.; Parr, R. G., Phys. Rev. B 1988, 37, 785-789.

Stephens, P.; Devlin, F.; Chabalowski, C.; Frisch, M., J. Phys. Chem. 1994, 98, 11623-11627.

Hay, P. J.; Wadt, W. R., J. Chem. Phys. 1985, 82, 270-283.

Ehlers, A. W., et al., Chem. Phys. Lett. 1993, 208, 111-114. 
Graphics for the Table of Contents

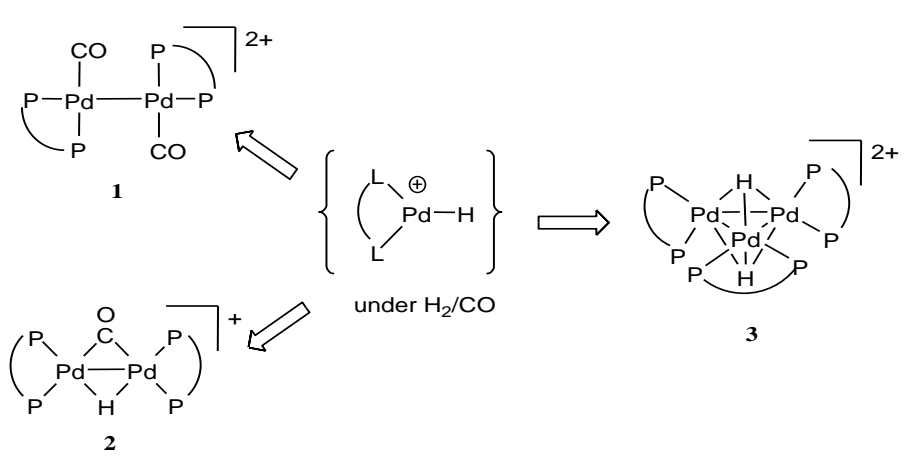

